NBER WORKING PAPER SERIES

\title{
CULTURE AND STUDENT ACHIEVEMENT: \\ THE INTERTWINED ROLES OF PATIENCE AND RISK-TAKING
}

\author{
Eric A. Hanushek \\ Lavinia Kinne \\ Philipp Lergetporer \\ Ludger Woessmann \\ Working Paper 27484 \\ http://www.nber.org/papers/w27484
NATIONAL BUREAU OF ECONOMIC RESEARCH
1050 Massachusetts Avenue
Cambridge, MA 02138
July 2020

We gratefully acknowledge comments from David Figlio, Nikki Shure, and seminar participants at the ifo Center for the Economics of Education in Munich. This work was supported by the Smith Richardson Foundation. The contribution by Woessmann is part of German Science Foundation project CRC TRR 190. The views expressed herein are those of the authors and do not necessarily reflect the views of the National Bureau of Economic Research.

NBER working papers are circulated for discussion and comment purposes. They have not been peer-reviewed or been subject to the review by the NBER Board of Directors that accompanies official NBER publications.

(C) 2020 by Eric A. Hanushek, Lavinia Kinne, Philipp Lergetporer, and Ludger Woessmann. All rights reserved. Short sections of text, not to exceed two paragraphs, may be quoted without explicit permission provided that full credit, including $\odot$ notice, is given to the source. 
Culture and Student Achievement: The Intertwined Roles of Patience and Risk-Taking

Eric A. Hanushek, Lavinia Kinne, Philipp Lergetporer, and Ludger Woessmann

NBER Working Paper No. 27484

July 2020

JEL No. I21,Z10

\begin{abstract}
$\underline{\text { ABSTRACT }}$
Patience and risk-taking - two cultural traits that steer intertemporal decision-making - are fundamental to human capital investment decisions. To understand how they contribute to international differences in student achievement, we combine PISA tests with the Global Preference Survey. We find that opposing effects of patience (positive) and risk-taking (negative) together account for two-thirds of the cross-country variation in student achievement. In an identification strategy addressing unobserved residence-country features, we find similar results when assigning migrant students their country-of-origin cultural traits in models with residencecountry fixed effects. Associations of culture with family and school inputs suggest that both may act as channels.

Eric A. Hanushek

Hoover Institution

Stanford University

Stanford, CA 94305-6010

and NBER

hanushek@stanford.edu

Lavinia Kinne

ifo Center for the Economics of Education

Poschingerstr. 5

81679 Munich

Germany

Kinne@ifo.de

Philipp Lergetporer

Ifo Institute for Economic Research

Poschingerstr. 5

81679 Munich, Germany

lergetporer@ifo.de

Ludger Woessmann

University of Munich

ifo Institute and CESifo

Poschingerstr. 5

81679 Munich, Germany

woessmann@ifo.de
\end{abstract}




\section{Introduction}

Each release of international student assessment data such as the PISA test brings both professional and popular discussions of the causes of national score differences. ${ }^{1}$ Score differences attract widespread attention not only because of the national ranking aspect but also because they provide indices of skills that are important for both future individual earnings and national economic growth. ${ }^{2}$ Yet the underlying reasons for national differences in performance are not well understood. One often discussed but seldom analyzed factor is cultural differences. This paper, relying on newly available measures of time preferences and attitudes about risk across countries, establishes a clear case for an important linkage of culture and educational performance and finds that international differences in patience and risk-taking are strongly related to international differences in student achievement.

Past research gives a mixed picture of the sources of test-score differences across countries. ${ }^{3}$ Commonly available measures of educational resources such as aggregate spending, class size, and teachers' experience and education explain little of existing score variation. ${ }^{4}$ On the other hand, institutional characteristics of school systems including test-based accountability, local autonomy, and private-school competition provide some explanation of score differences. Additionally, the role of parents and families is consistently strong, although quite variable across countries. Taken together, these aggregate factors provide a clear stylized picture of the relative roles of families, resources, and school institutions as proximate inputs into the international variation in test scores. Yet, the deeper structural determinants of international differences in societal choices of schooling inputs and in the productivity with which they are converted into educational outcomes remains poorly understood.

We focus on the potential role of cultural differences across societies as constituting fundamental determinants of student achievement differences. Our conceptual framework combines the usually separated literatures about optimal human capital investment and about

\footnotetext{
${ }^{1}$ The Programme for International Student Assessment (PISA) of the Organisation for Economic Co-operation and Development (OECD) provides test scores of random samples of 15-year-old students on a three-year cycle since 2000. Its latest installment in 2018 covers 75 countries (and four sub-country regions, see OECD (2019)).

${ }^{2}$ Achievement assessments are strongly related to both individual earnings (Hanushek et al. (2015, 2017)) and international growth differences in the aggregate (Hanushek and Woessmann $(2012,2015)$ ).

${ }^{3}$ Details behind the following overall summary statements from the existing research can be found in Hanushek and Woessmann (2011) and Woessmann (2016b).

${ }^{4}$ One recent study finds that a portion of the test-score differences across countries can be attributed to teacher cognitive skills (Hanushek, Piopiunik, and Wiederhold (2019)).
} 
education production functions in order to highlight the central nature of preferences underlying intertemporal decision-making. At their heart, educational choices and human capital investment decisions are inextricably linked to intertemporal outcomes. Moreover, while investment decisions are generally viewed from the individual perspective, many decisions on educational inputs - in particular about resources and school institutions - are taken at the group level rather than the individual level, making it hard to disentangle impacts of individual preferences from the cultural aspect of group preferences.

Two components of cultural traits are central to the relative valuation of net payoffs that accrue in the present versus in the future: time preferences (patience) and risk preferences (risktaking). Human capital investment decisions take time to effectuate and even longer before any returns are realized. Just as the rewards for schooling investments require patience on the part of the investor, national differences in patience may filter through into national differences in educational outcomes. Decisions to invest in human capital also involve considerable risk, and different channels ranging from chances of successfully completing schooling to variations in wages and employment in the future predict opposing effects of risk attitudes. Interestingly, because of the focus of optimal investment studies on labor-market outcomes, their analysis of risk has completely ignored how risk might enter into the production process itself. If we focus on the schooling process, elements emphasized in the crime literature (e.g., Freeman (1999)) come into play: A culture of risk aversion may discourage students from getting into trouble, thus spurring their effort in studying and carrying through to their educational performance. Importantly, the intertemporal nature of human capital investment, its inherent riskiness, and the interrelatedness of the two preference components imply that one cannot consider the impact of patience without simultaneously considering risk-taking, and vice versa.

Our empirical investigation of these cultural linkages is made possible by the recent innovations in international preference measurement in Falk et al. (2018). Their Global Preference Survey (GPS) employs experimental means to validate survey instruments that can be used to collect systematic data on international differences in several preference parameters. As such, the GPS establishes scientifically-grounded measures of culture that provide a means to test hypotheses central to models of human capital investment.

We combine the GPS data with PISA data on the educational achievement of close to two million students observed in seven waves from 2000-2018 across 49 countries. These data allow 
us to estimate international education production functions at the student level that bring out how country differences in cultural traits affect the skills acquired by students.

Our baseline analysis finds a strong and competing relationship between the two intertemporal cultural traits and students' educational achievement. Patience has a strong positive and risk-taking a strong negative association with test scores. The substantial positive correlation between the two implies that looking at these cultural values individually gives very misleading results and that it is important to condition on the one when interested in the effect of the other.

Together, the two aggregate intertemporal cultural components account for two-thirds of the variation in country average scores. Thus, a significant portion of the cross-country variation in student achievement may be closely related to fundamental cultural differences that play out in human capital investment decisions. Consistent with a leading role of national cultures, the associations of cultural measures with individual achievement are much stronger for native students than for migrant students who moved into the school system from another culture. Moreover, these findings are stable across separate subjects (math, science, and reading) and subsamples (OECD and non-OECD).

To explore the causal structure of these cross-country associations, we turn to an identification strategy that focuses on the migrant students in the PISA data. Across 48 residence countries, we observe the country of origin of over 80,000 migrant students from 58 countries of origin with data on culture. Following Figlio et al. (2019), we assign migrant students the culture of their country of origin and study the performance of migrant children from different cultures observed in the same residence country. We include fixed effects for each residence country in order to separate the effects of cultural factors from potentially correlated effects of the education systems, economies, or other common features of the residence country.

Students from home-country cultures with an aggregate one standard deviation higher patience perform about 90 percent of a standard deviation better in math, whereas students from home-country cultures with one standard deviation higher risk-taking perform about 30 percent of a standard deviation worse. Consistent with an intergenerational persistence of home-country culture, results are larger for migrant students who speak the language of their home country rather than of their current residence country at home. While this migrant analysis cannot rule out all potential biases in the cross-sectional analysis, robustness across different country samples, subjects, alternative cultural measures, definitions of the migrant population, different 
amounts of student test-taking effort, and several adjustments for the selectivity of migration shows that our results are insensitive to the most obvious threats to identification.

In order to investigate various channels through which cultural traits might influence student achievement, we link culture to the proximate inputs of the education production function in a final descriptive analysis. Patience is significantly positively correlated with aggregate indicators of family inputs, school inputs, and residual achievement differences (which likely combine productivity differences with unobserved inputs) across countries. Risk-taking is negatively correlated with family and residual inputs. Results are consistent with culture working through various input channels, with a particularly important role for family and residual inputs.

Our analysis of student assessment scores follows the recent literature investigating the influence of cultural factors on economic behavior and outcomes (see Guiso, Sapienza, and Zingales (2006) and Alesina and Giuliano (2015) for reviews). With our migrant student analysis, we also contribute to this literatures' focus on intergenerational transmission (e.g., Bisin and Verdier (2011); Alesina and Giuliano (2014); Chetty et al. (2017)). Past study of international student achievement has treated culture largely as a source of possible bias in estimating the effects of different proximate inputs in a cross-country setting (e.g., Hanushek and Woessmann (2011); Woessmann (2016b)). Here we show the value of directly addressing the potentially more fundamental role of cultural traits as underlying causes of achievement score differences in their own right, explaining previously unanalyzed elements of the nature of societal human capital investment decisions and the resulting human capital formation.

One central feature of our analysis is combining the two artificially separated strands of human capital literature: optimal investment decisions by individuals and the educational production process for skill development. The human capital investment literature following Mincer (1958), Becker (1964), Ben-Porath (1967), and others has measured human capital by individuals' years of schooling, equating skill development directly to the time costs of the investment. Human capital investments are portrayed as an individual intertemporal optimizing decision involving varying time commitments over the life cycle. The education production function literature on the other hand focuses on individuals' qualitative skill differences, generally looking at individuals with the same investment of school years but with different investment inputs by the individuals and by public entities (e.g., Hanushek (1986)). With some variations, the relevant skills are related to inputs of the individual and family and of the public 
through various aspects of schooling. We believe that these two lines of research are in essence looking at the same issue - how human capital investment decisions translate into differences in economically relevant skills. It is possible to gain insights into the deeper forces affecting skill differences of individuals and nations by treating these lines of research jointly.

We contribute to the literature on preferences and behavior which emphasizes the roles of time preferences (e.g., Sutter et al. (2013); Golsteyn, Grönqvist, and Lindahl (2014); Figlio et al. (2019)), risk preferences (e.g., Levhari and Weiss (1974)), and their interrelatedness (e.g., Halevy (2008); Andreoni and Sprenger (2012); Castillo, Jordan, and Petrie (2019)). Our analysis also relates to work on long-run comparative development (e.g., Galor and Özak (2016); Dohmen et al. (2019)) and immigrants (e.g., Abramitzky and Boustan (2017)).

The next section provides a conceptual framework that discusses how cultural traits related to intertemporal choices enter the human capital production model. Section 3 describes the data on human capital outcomes (PISA scores) and on cultural differences in time and risk preferences (GPS data). Section 4 develops the baseline estimates of the relationship of culture and human capital across nations. Section 5 delves deeper into the causal structure using the analysis of migrant outcomes. Section 6 explores the association of culture with proximate input factors as possible channels of the culture-achievement relationship. Section 7 concludes.

\section{Conceptual Framework}

Our analysis of international differences in test scores is motivated by a desire to understand how different national cultures contribute to variations in human capital across nations. We start by depicting educational choices in a human capital investment model with intertemporal preferences, incorporating several prior lines of inquiry into human capital investments (section 2.1). We then focus on the production of skills in order to understand how cultural traits affect the individual and public choices of inputs into the education production function and the ultimate set of skills (section 2.2). Finally, we provide a deeper discussion of how patience and risk-taking enter separately and jointly into intertemporal decision-making (section 2.3).

\subsection{Education as Intertemporal Choice}

Educational decisions are fundamentally an intertemporal choice: initial investments of time, effort, and resources are set against expected future gains. Early human capital models thus directly related educational returns and investments to the rate at which future earnings are 
discounted (Mincer (1958, 1974); Becker (1964)). Further development of modern human capital theory naturally moved to optimal investment decisions of individuals, focusing on the maximization of lifetime earnings and stressing the time dimension of investments (Ben-Porath (1967, 1970); Heckman (1976); Rosen (1976)). The focus on a representative individual with perfect foresight precluded any deeper consideration of individual differences in intertemporal preferences. Given the intertemporal optimization decision, however, the two preference components related to balancing the present and the future - time and risk preferences - are crucial in understanding individual educational choices.

Surprisingly little explicit attention has been given to individual willingness to postpone gratification captured in patience, even though it is obviously a key element in the educational investment decision and thus in the earnings distribution. Detailed consideration of risk, by contrast, has entered human capital modeling at least since the contributions by Weiss (1972) and Levhari and Weiss (1974).

The models of optimal human capital investment almost always focus on decisions about the quantity of education, which becomes the measure of individual skills. This focus has been natural given the availability of data and the consistency with the view of human capital investment as one of time. The perspective has been extraordinarily successful: The basic lifetime earnings model of Mincer (1974) has made years of schooling virtually synonymous with human capital in a wide range of empirical studies. Yet, school quantity is an imperfect measure of the underlying skill development that prescribes the optimality of downstream quantitative decisions in models of skill formation (Cunha, Heckman, and Schennach (2010)) and that has future payoffs on the labor market (Hanushek and Woessmann (2008)).

\subsection{Human Capital Investment, Educational Production, and Culture}

Direct investigation of the production of skills has developed mostly separately from the study of optimal human capital investment (Hanushek (1986)). Research into skill development during the production stage focuses on what is actually learned, generally measured by achievement tests (rather than the time spent in school). ${ }^{5}$ This research almost exclusively considers issues of technical efficiency of input usage and of the productivity of different inputs

\footnotetext{
${ }^{5}$ Our focus on achievement scores does not imply a different interest from the school attainment work. We view the intermediate measures of adolescents' achievement as a good index of the ultimate skills of completed human capital investments. As an alternative, the Programme for International Assessment of Adult Competencies (PIAAC) measures the cognitive skills of adults, but analysis is hampered by limited country coverage.
} 
- without relation to human capital investment behavior. ${ }^{6}$ But in reality, the education production function depicts how chosen inputs relate to human capital, as the observed proximate inputs to skill development are themselves the result of human capital investment decisions.

Further, even though the canonical human capital production model depicts skills as a function of family and school inputs, it is difficult to presume that these measured outcomes perfectly reflect the optimizing decisions of parents. The process of skill acquisition involves numerous actors - including the students themselves, their peers and friends, families, neighborhoods, teachers, school principals, and so on. Each presumably is optimizing over a different value function that may include different intertemporal preference parameters. Because of different assessments of the long-run value from human capital investments and different valuation of present versus future costs and payoffs, children may for example choose effort levels according to a preference for playing football or computer games over studying math in a way that diverges from what parents deem optimal in their maximization calculus. ${ }^{7}$

Importantly, many of the relevant educational investment decisions are actually made at the group level. How much to invest in school resources is usually publicly chosen at the municipal, state, or country level. Similarly, the institutional structures of school systems - features such as school accountability, autonomy, and choice which have been shown to matter greatly for student outcomes (Hanushek and Woessmann (2011); Woessmann (2016b)) - are decided upon at the group level, and in most countries at the national level. As a consequence, aggregate societal intertemporal preferences will affect many parts of the education production process, making the set of preferences shared by the group important.

Therefore, in this paper we change the perspective from individual preferences to group culture. Guiso, Sapienza, and Zingales (2006), p. 23, define culture as "those customary beliefs and values that ethnic, religious, and social groups transmit fairly unchanged from generation to generation.” While different theoretical and empirical concepts and definitions exist (Alesina and Giuliano (2015)), relevant cultural values encompass the set of preferences shared by the group including the intertemporal preferences that we deem important for educational choices. ${ }^{8}$

\footnotetext{
${ }^{6}$ There are exceptions, for example, when the choices of parental investments are related to other inputs in the production function (Kim (2001); Todd and Wolpin (2003)).

${ }^{7}$ Children may also be less willing or able to solve the dynamic optimization problem, leading to behavioral biases that prevent them from pursuing their own long-run well-being (Lavecchia, Liu, and Oreopoulos (2016)).

${ }^{8}$ The concept of culture is related to the concepts of values, preferences, and personality traits and sometimes even subsumed in noncognitive skills, and the interrelations and distinctions between the concepts often remain
} 
A key element of the existing cultural analyses is an emphasis on values that are transmitted persistently across generations (Bisin and Verdier (2011); Alesina and Giuliano (2014)). This persistent transmission motivates our empirical strategy below that looks at measures of culture in the home countries of migrants. Empirically, looking at migrants living in the same residence country allows us to distinguish cultural factors from other features of the residence country such as institutions and economies (Carroll, Rhee, and Rhee (1994); Giuliano (2007); Fernández and Fogli (2009); Figlio et al. (2019)).

Recognition of intergenerational transmission also suggests some care in the specification of empirical models because common family factors may reflect cultural features. Analyses of educational production functions - whether within or across countries - commonly include measures of parental education (e.g., Hanushek (1986); Hanushek and Woessmann (2011)). But if national cultures influence human capital investment, parents' realized educational patterns may proxy the culture of their country. As such, they may partially be bad controls in the study of culture because they absorb part of the influence of cultural factors.

More generally, a country’s culture may affect all inputs in the education production process - on both the family and the school side - as well as the overall productivity with which these inputs are transformed into educational outcomes. This conceptualization implies that analyses of the effect of culture on student achievement should use very parsimonious specifications of the vector of control variables contained in the education production function.

\subsection{Patience, Risk-Taking, and their Interrelatedness}

While culture can encompass a wide variety of common traits, our interest in intertemporal decisions related to educational investments leads us to focus on two specific components: time preferences and risk preferences.

Time Preferences. The central role of the discount rate in models of optimal investment in human capital implies that time preferences are a key element of choices about whether to invest additional time, effort, and resources in improving educational outcomes. Preferences for payoffs in different time periods are reflected in patience, the trait of having a low rate of time discounting. For example, students must consider whether to give up play time with friends

vague. See Almlund et al. (2011) for an extensive discussion of the relationship between personality traits and preferences. 
today - the opportunity cost of studying in the afternoon - for higher rewards in the future, such as graduating from school with better grades or the opportunity to receive better-paying jobs. ${ }^{9}$

It is remarkable that empirical studies only recently have begun to link validated measures of time preferences among students directly to educational outcomes. For example, Sutter et al. (2013) show that experimentally elicited measures of patience among Austrian children are significantly related to field behavior, including reduced violations of schools' code of conduct. ${ }^{10}$ Using longitudinal Swedish data, Golsteyn, Grönqvist, and Lindahl (2014) find that adolescents’ time preferences are associated with human capital investments and lifetime outcomes. Castillo, Jordan, and Petrie (2019) show that experimentally elicited measures of discount rates among students in a school district in the U.S. State of Georgia are significantly related to high school graduation. Combining the Hofstede (1991) cultural measure with migrant students in Florida schools as well as with the PISA data, Figlio et al. (2019) show that students from cultures with greater long-term orientation perform better on several measures of educational achievement. ${ }^{11}$ At the macro level, Galor and Özak (2016) and Dohmen et al. (2019) show that time preferences are importantly related to economic and educational outcomes in the long run. ${ }^{12}$

Risk Preferences. Beginning with the empirical study of occupational choices by Weiss (1972) and the theoretical analysis in Levhari and Weiss (1974), a stream of studies of human capital investments explicitly introduced various components of uncertainty and risk. In a very general way, Levhari and Weiss (1974) consider a range of risky elements that occur at the time of investment decisions including future supply and demand conditions as well as knowledge of one's own ability, of how time and money convert into human capital, and of the quality of schools along the investment path. They show that it is not possible a priori to determine how

\footnotetext{
${ }^{9}$ As such, patience is closely related to similar concepts employed in the study of traits among children, such as the willingness to defer gratification as measured, e.g., by the famous "marshmallow test” (e.g., Mischel, Shoda, and Rodriguez (1989)), self-control (Moffitt et al. (2011)), or perseverance and grit (e.g., Duckworth et al. (2007)).

${ }^{10}$ Alan and Ertac (2018) and Alan, Boneva, and Ertac (2019) show that measures of patience and grit are malleable to classroom interventions.

${ }^{11}$ Mendez (2015) shows the potential relevance of culture for student achievement using a principal component from eleven different value questions in the World Values Survey (WVS) with migrant students in seven host countries in PISA, but the approach does not delve into specific cultural traits. Cordero et al. (2018) include WVS measures in efficiency measurement of school systems in PISA.

${ }^{12}$ While formulated from a different perspective, a recent literature suggests that student behavioral differences related to effort, care, motivation, and perseverance may impact country test scores (e.g., Borghans and Schils (2012); Balart, Oosterveen, and Webbink (2018); Akyol, Krishna, and Wang (2018); Gneezy et al. (2019); Zamarro, Hitt, and Mendez (2019)). These behavioral differences may in turn reflect underlying cultural differences. We return to the role of student test-taking effort in robustness analyses below.
} 
risk affects human capital investment incentives, a conclusion reiterated in the extensive review by Benzoni and Chyruk (2015). In line with the indeterminate nature of the impact of risk, higher earnings variance in higher-educated jobs may give rise to a positive association between risktaking preferences and investment in higher education (e.g., Hartog and Diaz-Serrano (2007, 2014)), whereas lower unemployment risk of higher-educated jobs (e.g., Woessmann (2016a)) may give rise to the opposite association. Focusing on student behavior and drawing on insights from the economics of crime, Castillo, Jordan, and Petrie (2019) argue that risk-lovingness may deter educational effort by favoring misbehavior in adolescence if there is uncertainty about getting caught by teachers or parents.

Existing empirical evidence on the association between risk and human capital investment is closely related to the specific components of risk considered in individual studies. Using U.S. data, Brown, Fang, and Gomes (2012) suggest that greater risk aversion leads to more investment in high-school education compared to less than high school but less investment in college compared to high school. Analyzing both wage and employment uncertainty, Groot and Oosterbeek (1992) find different results on returns by type of schooling (vocational or college) in the U.S. and the Netherlands, while Koerselman and Uusitalo (2014) find little differential effect of lifetime income variability on different schooling choices in Finland. Palacios-Huerta (2003) compares human capital risks to financial assets risk and detects wide variation in risk-adjusted rates of return. Using direct measures of children's risk preferences, Sutter et al. (2013) find little evidence of associations with field behavior, whereas Castillo, Jordan, and Petrie (2019) show a negative association of risk-taking preferences with high-school graduation. ${ }^{13}$

The Interrelatedness of Time and Risk Preferences. While much of the prior literature has considered time and risk preferences separately, behavioral economics has emphasized their inherent interrelatedness: since only the present can be certain and the future always contains an element of uncertainty, it is inescapable that the two preference components are intertwined (Halevy (2008); Andreoni and Sprenger (2012)). ${ }^{14}$

An important implication of this interrelatedness is the need to control for the one preference component when studying the effect of the other. In fact, because many of the studies of risk-

\footnotetext{
${ }^{13}$ There is also evidence of associations of patience and risk with intelligence among adults, again with mixed evidence on risk (Dohmen et al. (2010, 2018); Potrafke (2019)).

${ }^{14}$ Their particular formulation has been questioned, but the basic concept seems clear. See the exchange in Cheung (2015), Epper and Fehr-Duda (2015), Miao and Zhong (2015), and Andreoni and Sprenger (2015).
} 
taking do not control for patience, this interrelationship may help explain the reasons for the divergent empirical effects of risk on investment. Even more, given the a priori indeterminate direction of the effect of risk-taking in the human capital production function, the direction of bias when estimating the effect of patience without considering risk-taking is also unclear.

\section{Data}

Combined international data on student achievement from the Programme for International Student Assessment (PISA, section 3.1) and on preferences from the Global Preference Survey (GPS, section 3.2) support our investigation of how cultural traits relate to student learning.

\subsection{The Programme for International Student Assessment (PISA)}

The Organisation for Economic Co-operation and Development (OECD) has conducted the PISA international student achievement test since 2000. PISA assesses achievement in math, science, and reading of representative random samples of 15-year-old students - independent of grade level or educational track attended - on a three-year cycle (OECD (2019)). ${ }^{15}$ PISA provides repeated cross-sectional data that are representative in each country-by-wave cell, and only reports data for countries that meet the OECD’s high sampling and data-quality standards.

Over the seven waves of PISA testing, 2000-2018, a total of 86 countries participated in the PISA assessment at least once. Our baseline cross-country analysis considers the subset of 49 countries that are also covered by the GPS (see column 3 of Appendix Table A1 for a list of countries). In total, our baseline analysis uses achievement data from 1,992,276 students from 263 country-by-wave observations.

In our migrant analysis, we can include migrant students in any residence country as long as PISA identifies the country of origin and GPS data are available for that country. The entire 2000 PISA wave drops out of this analysis as it does not provide information on students' country of origin. Still, the country-of-origin perspective of this approach allows us to increase the total number of countries considered, covering 80,398 migrant students (and up to 145,506 in a wider definition) from 58 countries of origin (column 5 of Appendix Table A1) observed in 48 residence countries (column 4). As the samples of countries that can be included differs between

15 The sampling in most countries proceeds in two steps. First, a random sample of schools that teach 15-yearold students is drawn using sampling probabilities that assure representativeness. Second, 35 students aged 15 years are randomly sampled in each school. 
baseline analysis, residence countries in the migrant analysis, and countries of origin in the migrant analysis, the different parts of our analysis use data from a total of 86 countries, 71 of which participated in PISA and 64 of which have GPS data (columns 1 and 2). ${ }^{16}$

To create comprehensive measures of students' competencies, PISA has students complete a broad array of tasks of varying difficulty in assessments that last for up to two hours. The testing mode was paper and pencil until 2012 and changed to computer-based testing in 2015. PISA achievement in math, science, and reading were standardized to a mean of 500 test-score points and a standard deviation of 100 test-score points for OECD-country students in wave 2000 (and rescaled on the same metric again in 2003 in math and in 2006 in science). We divide PISA scores by 100 throughout to express achievement in percent of a standard deviation. As a rule of thumb for interpreting PISA scores, about a quarter to a third of a standard deviation corresponds to the learning gains of one year of schooling (Woessmann (2016b)). Appendix Table A2 shows descriptive statistics of country-level PISA achievement in the three subjects.

In addition to achievement data, PISA elicits background information on student and family characteristics using student questionnaires, as well as contextual information on school resources and the institutional environment using school questionnaires completed by school principals. From these rich background data, we select core control variables for our regression analysis. At the student level, these are gender, age, migration status (first and second generation), parental education (six categories), parental occupation (four categories), books at home (four categories), computer for school work at home (dummy), and other language than the test language spoken at home (dummy). School-level controls include school location (three categories), school size, share of fully certified teachers, and shortage of educational material (dummy). At the country level, we include GDP per capita, share of privately managed schools, share of government funding of schools, central exit exams (dummy), and a school-autonomy index. The share of missing values for these covariates is generally very low, averaging 5 percent. We impute missing values of control variables using the respective country-by-wave

\footnotetext{
16 The complex structure of country inclusion is explained in greater detail in the note to Appendix Table A1. In the migrant analysis, countries can be included as residence countries even if there are no GPS measures for them (as long as they participated in PISA and have migrant children from countries of origin that participated in the GPS) and as countries of origin even if there are no PISA measures for them (as long as they participated in GPS and have "sent" students as migrants to PISA-participating countries).
} 
mean and include imputation indicators (one dummy per control variable that equals one if the respective variable is missing and zero otherwise) in our regression analysis. ${ }^{17}$

\subsection{The Global Preference Survey (GPS)}

The newly available Global Preference Survey (GPS) provides validated, high-quality data on several preference parameters collected from representative samples in 76 countries (Falk et al. (2018)). It was conducted within the framework of the 2012 wave of the international Gallup World Poll, an annual survey on social and economic topics. Using probability-based sampling, the GPS covers a representative sample of around 1,000 respondents in each country. In our analysis, we collapse the GPS data at the country level to retrieve one representative measure for each preference parameter per country. In total, we use GPS data from 64 countries in our analysis (column 2 of Appendix Table A1) - 49 countries in the baseline cross-country analysis (column 3) and 58 as countries of origin in the migrant analysis (column 5).

The GPS uses twelve survey items to measure preferences in six domains: patience and risktaking (the two preference components underlying intertemporal decision-making that are our main focus here) plus positive reciprocity, negative reciprocity, altruism, and trust. The survey items were selected in an ex-ante validation exercise based on their ability to predict incentivized choices in a controlled laboratory setting. ${ }^{18}$ For most preference domains, this exercise led to the selection of a combination of one qualitative survey question and one hypothetical choice scenario. For instance, the qualitative survey item to measure patience elicits respondents’ answer to the following question on an 11-point Likert scale: "How willing are you to give up something that is beneficial for you today in order to benefit more from that in the future?" The hypothetical choice scenario for patience entails a series of binary decisions between 100 Euro today or a higher amount in 12 months: "Suppose you were given the choice between receiving a payment today or a payment in 12 months. We will now present to you five situations. The payment today is the same in each of these situations. The payment in 12 months is different in every situation. For each of these situations we would like to know which one you would choose. Please assume there is no inflation, i.e., future prices are the same as today's prices. Please

\footnotetext{
${ }^{17}$ In the few cases where a covariate is missing for an entire wave in a given country, we impute by averaging over the country's other PISA waves. Dropping these country-by-wave observations as a robustness check does not affect our results (results available upon request).

${ }^{18}$ In the validation exercise, students at the University of Bonn took different incentivized decisions and answered numerous survey questions for each preference domain (Falk et al. (2016)).
} 
consider the following: Would you rather receive amount $x$ today or $y$ in 12 months?" The validation exercise was used to select similar survey questions for the other preference domains (see Falk et al. (2018) for details). ${ }^{19}$ For each domain, the selected survey items are then combined into a single preference measure using weights from the validation procedure. The GPS dataset does not provide responses to individual items, so we use the available combined preference measures in our analysis.

Larger values of patience mean the individual is more likely to accept deferred gratification. Larger values of risk-taking mean that the individual is more likely to take risky outcomes compared to certain outcomes. The GPS dataset contains one $z$-standardized variable for each preference domain. Standardization is conducted at the individual level so that each preference has mean zero and standard deviation one in the individual-level world sample. For the purpose of our analysis, we $z$-standardize each individual preference measure in our respective analytical sample and collapse standardized preference measures at the country level. Appendix Table A2 presents descriptive statistics of the resulting data.

Consistent with the interrelation emphasized in the behavioral literature, patience and risktaking are strongly positively correlated in the GPS data. Figure 1 depicts the cross-country association between the two preference components in the 49-country sample of our baseline analysis, where the significant correlation is 0.358 . Appendix Table A3 shows country-level correlations for all preference measures. While patience is not significantly correlated with the other four GPS preference domains (although there are marginal correlations with negative reciprocity and trust), there is a significant correlation of risk-taking with negative reciprocity.

The GPS has several important advantages over alternative international datasets with proxies for cultural traits, because it provides scientifically validated measures of the two preference components underlying intertemporal decision-making from representative samples for a large set of countries. The closest alternatives are the World Values Survey (WVS) and the Hofstede (1991) data, both of which provide survey data on attitudes, beliefs, and personality

\footnotetext{
${ }^{19}$ Exceptions are trust and negative reciprocity, which are measured using one and three qualitative survey questions, respectively. For risk-taking, the qualitative 11-point-scale question is: "In general, how willing are you to take risks?" The quantitative staircase measure is based on the question: "Please imagine the following situation. You can choose between a sure payment of a particular amount of money, or a draw, where you would have an equal chance of getting amount x or getting nothing. We will present to you five different situations. What would you prefer: a draw with a 50\% chance of receiving amount $x$, and the same $50 \%$ chance of receiving nothing, or the amount of y as a sure payment?"
} 
traits across countries. While the WVS is based on representative samples, the Hofstede data are mainly based on IBM employees and are not representative. Importantly, in contrast to the GPS, the validity of the proxies for patience, risk-taking, and other cultural domains from these surveys is unknown. ${ }^{20}$ Reinforcing the high quality of the GPS data, Falk et al. (2018) show that the GPS patience measure is more predictive of comparative economic development than the measures of long-term orientation from the other two datasets. Interestingly, the correlations of the GPS measures of patience and risk-taking with their respective proxies in the WVS and Hofstede datasets are limited: The correlations of GPS patience with the WVS and Hofstede long-term orientation measures are -0.060 and 0.247 , respectively, and statistically insignificant (Appendix Table A3). The correlations of GPS risk-taking with WVS risk-taking and Hofstede uncertainty avoidance are only slightly stronger at 0.239 and -0.302 , respectively. For our robustness analyses, however, we investigate the WVS and Hofstede data as alternative measures for patience and risk-taking (see sections 4.3 and 5.3).

\section{Culture and International Differences in Student Achievement}

Our analysis begins with a description of the association of student achievement with patience and risk-taking across countries. We introduce the empirical model of an international education production function (section 4.1) and report our baseline results (section 4.2) and various robustness analyses (section 4.3). These descriptive results guide our subsequent analysis of the causal structure of the cross-country associations in section 5 .

\subsection{Empirical Model}

Our empirical approach contrasts with most empirical investigations of educational production functions that include a long list of possible variables in order to soak up potential impacts of families, schools, institutions, and culture. Being interested in more fundamental determinants of differences in educational achievement across countries, we use the

\footnotetext{
${ }^{20}$ For instance, the best proxy for patience in the WVS is an item on "long-term orientation" that asks "Here is a list of qualities that children can be encouraged to learn at home. Which, if any, do you consider to be especially important?" and is coded 1 if the respondent selects the item "thrift, saving money and things", and 0 otherwise. The Hofstede dataset contains proxies for long-term orientation and uncertainty avoidance that are composed of a collection of four qualitative survey items each, several of which appear somewhat unrelated to the concepts that they mean to measure. For example, long-term orientation includes an item on "How proud are you to be a citizen of your country?" and uncertainty avoidance includes an item on "All in all, how would you describe your health these days?" (see footnote 7 in Falk et al. (2018) for details).
} 
parsimonious specification of an education production function that models the output of education as centrally determined by cultural traits:

$$
T_{i c t}=\beta_{1} \text { Patience }_{c}+\beta_{2} \text { Risk }_{c}+\alpha_{1} B_{i c t}+\mu_{t}+\varepsilon_{i c t}
$$

where achievement $T$ of student $i$ in country $c$ at time $t$ is a function of the two intertemporal cultural traits of the country, a parsimonious vector of baseline controls $B$ (student gender, age, and migration status), and an error term $\varepsilon_{i c t}$. Fixed effects for test waves $\mu_{t}$ account for average changes over time along with any idiosyncrasies of the individual tests. Our coefficients of interest are $\beta_{1}$ and $\beta_{2}$ which characterize the relationship between the two cultural traits of a country's society - patience and risk-taking - and student achievement.

To account for the country-level nature of the main treatment variables, we cluster standard errors at the country level throughout. All regressions are weighted by students' sampling probabilities within countries and give equal weight to each country.

Because culture is a multifaceted concept, it is important to ensure that the associations are not driven by other cultural features. Appendix Table A3 indicates little interrelatedness of the two intertemporal cultural traits with other cultural domains. Nonetheless, in some specifications we control for the additional cultural factors of the GPS data.

Estimates of education production functions usually contain measures for proximate inputs family inputs, school resources, and institutional features. To the extent that these proximate inputs are themselves the outcomes of intertemporal choice decisions, they would be bad controls in a model depicting the overall effect of intertemporal cultural traits on student achievement. Including proximate input factors in our model, however, provides a descriptive evaluation of the importance of these input channels and shows the robustness of the cultureachievement association to consideration of variation in input factors that stem from other sources. Therefore, we also report specifications that include a rich set of control variables for proximate input factors that would generally be included in education production functions:

$$
T_{i c t}=\beta_{1} \text { Patience }_{c}+\beta_{2} \text { Risk }_{c}+\alpha_{1} B_{i c t}+\alpha_{2} F_{i c t}+\alpha_{3} S_{i c t}+\alpha_{4} I_{c t}+\mu_{t}+\varepsilon_{i c t}
$$

which additionally includes measures of the inputs from student's families $F$, schools $S$, and institutional structures of school systems $I$. 


\subsection{Results of the Baseline Analysis}

Our baseline analysis of the association of student achievement with cultural traits across countries is shown in Table 1. The first panel uses math achievement on the 2015 PISA test - the first PISA wave after the elicitation of the GPS data in 2012 - in the cross-country regression analysis of equation (1).

Results indicate important and intertwined roles of patience and risk-taking in international student achievement. When entered individually, there is a strong and significant positive association of student achievement with patience (column 1) and a weaker and insignificant negative association with risk-taking (column 2). Strikingly, both associations become much stronger (in absolute terms) and statistically highly significant when the two cultural traits are considered together (column 3), highlighting the importance of accounting for their interrelatedness. A one standard deviation (s.d.) increase in patience is associated with more than a one s.d. increase in student achievement, whereas the same increase in risk-taking is associated with more than a one s.d. decline in student achievement. Conditioning on the other cultural trait is particularly relevant in the case of risk-taking: That part of the variation in risk-taking that is unrelated to patience has a strong negative association with student achievement.

The results on the two intertemporal cultural traits are hardly affected when taking measures of other cultural traits into account (column 4). In fact, none of the other four GPS measures positive reciprocity, negative reciprocity, altruism, and trust - is quantitatively or statistically significantly associated with student achievement across countries. Thus, the cultural components directly linked to intertemporal decision-making, rather than other preference domains, appear most relevant for educational achievement.

Pooling the achievement data of all PISA waves (2000-2018) is justified because culture by definition is focused on traits that are fairly unchanged over the long run. Moreover, the vast majority of country variation in PISA scores is between countries rather than over time. Pooling extends the country sample and provides more precise measures of long-run educational achievement. Going from the 2015 wave to the pooled seven-wave sample expands the country coverage from 41 to 49 countries and the student sample from just over 300,000 to nearly 2 million. Interestingly, results in the expanded sample (columns 5 and 6) are qualitatively the same as in the 2015 PISA wave, indicating that the pooled analysis is not affected by the relative timing of the observation of cultural and achievement data. 
The interrelationship of the intertemporal cultural traits and achievement is depicted graphically in Figure 2. The upper panel shows simple bivariate scatterplots between average PISA math scores (pooled across all waves) and the GPS measures of patience (left) and risktaking (right) at the country level. There is a strong positive association of student achievement with patience and a weaker and less precise negative one with risk-taking. At the country level, the $R^{2} \mathrm{~s}$ of the underlying regressions suggest that patience alone accounts for 40.9 percent of the cross-country variance in achievement, whereas risk-taking alone accounts for only 6.2 percent of the variance. Both associations become much stronger and more precise when conditioning on the respective other cultural trait in the lower panel. ${ }^{21}$ The two cultural traits together account for two-thirds of the variance in average student achievement across countries $\left(R^{2}=0.672\right)$. Interestingly, this is substantially larger than the sum of explained variance accounted by the two measures separately, underscoring the interplay of the two cultural traits. The figures also show that the overall associations are not driven by any strong outliers.

The coefficient estimates on the two cultural traits remain large and statistically highly significant, but are reduced in size, when adding controls for proximate inputs to the model (columns 7-8 of Table 1). As discussed above, the extended set of controls for family, school, and institutional inputs (described in the table notes) are likely bad controls because they too are outcomes of the deeper cultural traits. The reduction of the coefficients on patience by 39 percent and on risk-taking by 33 percent (when comparing columns 5 and 8) in this descriptive analysis indicates that a substantial part of the overall effects of the two cultural traits may work through the channels of these proximate inputs. We provide a closer analysis of the association of the different input factors with the two cultural traits in section 6 below.

If culture is driving the achievement results, one would expect the residence-country culture to be less important for migrants whose parents are less steeped in that culture and whose exposure to the new culture is less. When we look separately at native students and migrants, we find a much stronger role of residence-country culture for native students than for migrant students. Table 2 shows that among native students, a one s.d. increase in patience is associated

${ }^{21}$ The added-variable plot in the lower left panel is created by first regressing both variables (math achievement and patience) on risk-taking. The residuals of the two regressions are then plotted against each other. These residuals represent the part of the variation in both variables that cannot be accounted for by risk-taking, assuring that risk-taking does not drive the depicted association. This exercise is numerically equivalent to regressing math achievement on patience and including risk-taking as a control variable. The equivalent procedure is used in the lower right panel. 
with 1.30 s.d. higher achievement, and the same increase in risk-taking is associated with 1.32 s.d. lower achievement (column 1). By contrast, among students with a migrant background the association is much lower ( 0.70 s.d.) for patience and only marginally significant (at 0.37 s.d.) for risk-taking (column 2). ${ }^{22}$

The difference in results between students with and without migration background is in line with a leading role of culture as a deep determinant of student achievement rather than other unobserved schooling factors of the country. It also motivates our migrant analysis below that considers the cultural traits of the countries of origin from which the migrant students migrated.

\subsection{Robustness Analysis}

Country subsamples. To test whether our main results differ by level of development, columns 3 and 4 of Table 2 present separate regressions for OECD countries and non-OECD countries, respectively (measured as ever belonged to OECD). The qualitative pattern of our findings is very similar and does not differ significantly between the two subsamples.

In additional subsample analyses, we re-estimated the pooled models in Table 1 (columns 5, 6, and 8) excluding one wave or one country at a time. Qualitative results are insensitive to this alteration. The coefficients on patience and risk-taking remain significant in all these regressions (not shown).

Additional subjects. Results are also very similar for achievement in science and reading rather than math (columns 5 and 6 of Table 2). In science, a one s.d. increase in patience (risktaking) is associated with a test-score increase (decrease) by 1.12 s.d. (1.17 s.d.). In reading, the corresponding coefficient is 1.11 s.d. (1.13 s.d.). Thus, the reported associations are universal in the sense that they do not depend on a particular subject.

Accounting for test-taking effort. One interpretational concern with low-stakes achievement tests such as PISA is that they might not only measure students' cognitive skills but also their effort on the test itself which in turn may depend on students' conscientiousness, intrinsic motivation, and other related skills (e.g., Borghans and Schils (2012); Akyol, Krishna, and Wang (2018); Gneezy et al. (2019)). Among a number of measures of students' test-taking effort derived for the 2009 PISA wave, Zamarro, Hitt, and Mendez (2019) find that the extent of item nonresponse (the share of unanswered questions) in the student background questionnaire

\footnotetext{
${ }^{22}$ Students are classified as migrants if both parents were born abroad. The migrant analysis in section 5 shows that our findings are insensitive to alternative definitions of the migrant population.
} 
that follows the actual achievement test explains the largest share of cross-country variation in test scores. We construct this measure for all PISA waves to test whether the strong association of the two intertemporal cultural traits with PISA achievement partly reflects lower test-taking effort among less patient and more risk-taking students. The measure of test-taking effort is indeed significantly associated with the two cultural traits: Countries with lower patience and higher risk-taking preference have higher item nonresponse on the background questionnaire. The bivariate association of test-taking effort with patience is particularly strong at -0.29 .

While test-taking effort is indeed relevant for overall test achievement, it does not alter the results for the two cultural traits. Individual students' item nonresponse rates on the background questionnaire negatively predict achievement on the math test (column 7 of Table 2). But the coefficients on patience and risk-taking hardly change. The same is true when we additionally control for average item nonresponse of the country (column 8). This is despite the fact that item nonresponse has substantial quantitative relevance: At the country level, the coefficient estimate suggests that going from the country with the lowest $(0.010)$ to the highest $(0.108)$ average share of unanswered items in the background questionnaire decreases the average PISA score by 0.40 s.d. It seems that the issue of test-taking effort, while relevant, is specific to low-stake test taking and does not intervene with the more fundamental culture-achievement nexus.

Alternative cultural measures. Given the rather vague measurement of the underlying intertemporal concepts in the WVS and Hofstede datasets (section 3.2), we are less confident about the validity of these alternative measures of cultural traits. Still, Appendix Table A4 shows that the WVS cultural measures yield a similar pattern of a positive association of student achievement with long-term orientation and a negative association with risk-taking (column 1). Using the Hofstede measures, long-term orientation is significantly positively associated with student achievement, whereas uncertainty avoidance is insignificant (column 2). ${ }^{23}$

\section{Exploration into Causality: Migrant Analysis}

An obvious concern with cross-country regressions of student achievement on cultural traits is that a country's culture is likely correlated with other omitted country characteristics, such as legal or economic factors. While some of the variation in these country factors may be the

\footnotetext{
${ }^{23}$ In a specification that includes all cultural measures from the GPS, WVS, and Hofstede together, only the GPS measures of patience and risk-taking remain large and statistically significant, whereas the WVS and Hofstede measures lose their statistical significance (not shown).
} 
outcome of the cultural traits and thus constitute channels rather than omitted variables, there may also be independent variation that happens to be associated with the cultural measures. For instance, a culture of patience might foster the economic development in a country more broadly, making it impossible to distinguish whether a positive association between patience and student achievement is due to patience per se or rather better well-being. To address concerns about the causal interpretation of the baseline analysis, we explore an identification strategy that analyzes cultural differences among migrants. The empirical strategy is introduced in section 5.1, followed by the main results in section 5.2 and robustness analyses in section 5.3.

\subsection{Empirical Model}

If patience and risk-taking truly are cultural factors that affect educational investment decisions, migrants with parents from different countries should retain some influence of the culture of their home countries. Thus, we begin by assigning each migrant student the culture of her country of origin. If we then compare achievement across migrant children from different cultures who attend school in the same country of residence, we break the link between culture and elements of the schools, institutions, and environments of the country of schooling something that cannot be done for natives. Following similar applications in Carroll, Rhee, and Rhee (1994), Giuliano (2007), Fernández and Fogli (2009), and Figlio et al. (2019), we estimate regressions of the following form:

$$
T_{\text {ioct }}=\delta_{1} \text { Patience }_{o}+\delta_{2} \text { Risk }_{o}+\gamma_{1} B_{\text {ioct }}+\theta_{c} \times \mu_{t}+\varepsilon_{\text {ioct }}
$$

where $T$ is achievement of migrant student $i$ from country of origin $o$ observed in residence country $c$ at time $t$. Patience Pand $_{\text {Ris }}$ are the respective cultural traits measured in the country of origin.

Importantly, our specification includes residence-country fixed effects $\theta_{c}$ to remove all common economic, institutional, and schooling factors for each residence country. We pool the data across residence countries but only use variation within each residence country and not cross-country variation to estimate the cultural impacts. In a first specification, we include fixed effects for residence countries $\theta_{c}$ and for waves $\mu_{t}$ separately. We also go further to control for a full set of residence-country by wave fixed effects $\theta_{c} \times \mu_{t}$ that nest the separate residence-country and wave fixed effects and account for wave-specific achievement differences across countries. Standard errors are clustered at the country-of-origin level. 
In our main migrant analysis, we adopt a rather narrow definition of migrants, including only students with parents who are both born in a different country than the testing country. We assign first-generation migrant students their country of birth and second-generation migrant students the country of origin of their father. Across all PISA waves, there are 80,398 first- and second-generation migrants from 58 countries of origin observed in 48 residence countries for whom we observe a country of origin with available GPS data.

\subsection{Results of the Migrant Analysis}

The migrant analysis confirms the strong positive effect of patience on student achievement from the baseline analysis, as well as a significant negative effect of risk-taking, albeit of smaller magnitude compared to its baseline estimate and to the effect of patience. Table 3 reports the main regression results for the migrant analysis based on equation (3). All regressions include 48 fixed effects for the respective residence countries, six fixed effects for waves, and baseline controls. When entered separately, student achievement is significantly positively related to patience in the students' home country (column 1) and insignificantly positively to risk-taking (column 2). In line with the baseline cross-country findings, the coefficient on patience increases substantially and the coefficient on risk-taking turns significantly negative when both are entered together (column 3), underscoring the interrelated and competing nature of the two cultural traits.

Columns 4-6 go one step further and control for 180 residence-country by wave fixed effects to account for wave-specific residence-country differences in student achievement. This alteration leaves the coefficients of interest largely unchanged. In this specification, students from home-country cultures with one s.d. higher patience perform 0.93 s.d. better on the PISA math assessment, and students from home-country cultures with one s.d. higher risk-taking perform 0.29 s.d. worse.

Column 7 additionally includes controls for the four other cultural traits of the country of origin. Similar to the cross-sectional analysis, these cultural controls do not significantly affect student achievement and leave the significant effects of the two intertemporal cultural traits intact. In fact, the coefficient on risk-taking increases (in absolute terms) to -0.45 in this specification.

Column 8 adds the set of extended controls on family and school inputs in the residence country, as well as the country of origin's GDP per capita. This latter control addresses the concern that, for instance, better performance of migrants from high-patience countries merely 
reflects differences in income (as opposed to genuine effects of culture). As expected, the coefficient on patience is reduced in this specification (because the family and GDP controls may take out some of the total effect of culture), but it remains large and significant (as does the coefficient on risk-taking).

In sum, the migrant analysis confirms the strong and positive effect of patience on student achievement documented in the descriptive cross-country analysis, even with the same overall magnitude. Similarly, it replicates the negative effect of risk-taking once we account for patience, though the effect size is somewhat smaller. The migrant analysis rules out that the cross-country results are due to omitted residence-country variables. There is, of course, the possibility of remaining biases, some of which we address in the following robustness tests.

\subsection{Robustness Analysis}

\section{Country subsamples, additional subjects, test-taking effort, and alternative cultural} measures. Again, results do not differ significantly by the level of development of migrants' countries of origin. Patience enters significantly positively, and risk-taking significantly negatively, in the subsamples of migrant students from both OECD and non-OECD countries of origin (columns 1 and 2 of Table 4). The positive point estimate of patience is somewhat larger in OECD countries, whereas the negative point estimate of risk-taking is somewhat larger (in absolute terms) in non-OECD countries. However, neither difference is statistically significant.

Columns 3 and 4 present results for student achievement in science and reading, respectively. Results are again very similar to math, although the negative coefficient on risktaking is not statistically significant in the other two subjects.

To account for differences in students' test-taking effort, columns 5-7 control for individual and country-of-origin mean item nonresponse rates in the PISA student background questionnaires. Again, the results on patience and risk-taking hardly budge after controlling for these proxies for student effort, although both enter significantly in explaining scores.

The qualitative pattern of results on patience is also confirmed with the alternative measures in the WVS and Hofstede datasets (columns 3 and 4 of Appendix Table A4). In both cases, there is a significant positive effect of long-term orientation on student achievement, in line with the results in Figlio et al. (2019). The WVS data also confirm a significant negative effect of risktaking. By contrast, the Hofstede risk measure points in the opposite direction - a negative effect 
of uncertainty avoidance - which presumably reflects the poor measurement of the underlying concept by the items contained in this proxy (see section 3.2).

Different migrant subgroups. Identification in the migrant analysis depends on the extent to which the cultural values of the country of origin provide a good proxy for the students' and families' actual cultural values. A first approach to assess this question distinguishes migrants by dosage of culture, i.e., by the time at which the students themselves migrated to the country of residence. Results in columns 1 and 2 of Table 5 show that the effect of patience does not differ significantly between second-generation migrants (born in the residence country after their parents had migrated) and first-generation migrants (born in the country of origin), and the negative effect of risk-taking is actually larger for second-generation migrants.

We can exploit information on the age of migration in our dataset to subdivide the firstgeneration migrants further by whether they arrived in the residence country before or after age 6 , when they would usually start school. Within the first-generation migrants, the effects of the two cultural traits do not differ by whether students had migrated earlier or later (columns 3 and 4). While these patterns show the robustness of our main findings, they do not support the notion that later migrants hold onto more of their country-of-origin culture.

Perhaps a better proxy for the extent to which the students' families still hold their country of origin's culture is whether they still speak the language of their country of origin at home, rather than adopting the language of their new host country when talking among themselves. The PISA data provide information on the language spoken at home. And, indeed, the effects of the two home-country cultural traits are 0.17 and 0.20 s.d. larger for those students who do not yet speak the residence-country language at home compared to those who do (columns 5 and 6). These results are consistent with an interpretation where the treatment variables in the migrant analysis do in fact capture the impact of cultural values of the countries of origin.

Alternative migrant definitions. Our main specification uses the country of origin of the students' fathers for reference for second-generation migrant students. Results in the first column of Table 6 show that estimates are virtually identical when the country of origin of the mother is used instead. Column 2 uses the average value of the cultural traits of the country of origin of both parents when both are available, and the measure of the respective country of origin of the father or mother if the information is available only for one of them. Again, results hardly change in the slightly larger sample of 83,798 students. 
As the PISA data allow us to observe both parents' country of origin, we can also enter the cultural traits of fathers' and mothers' country of origin simultaneously (column 3). While this horse-race specification is identified only from children whose parents come from different countries, results still provide a relatively clear pattern. The effect of patience is significantly positive for both parents' cultures, although it is twice as large for fathers' compared to mothers' patience. By contrast, the effect of risk-taking is fully driven by fathers' culture, with risk-taking of the mothers' country of origin not entering migrant students’ achievement.

In our main specification, we adopt a rather narrow definition of migrants that includes only students whose parents are both born in a different country than the testing country. Alternatively, we can use a wider definition that includes all students with at least one parent born abroad - defining as natives only those with both parents born in the testing country. This wider definition increases the number of observations to over 140,000 migrant students. While, expectedly, point estimates are slightly smaller with this broader measurement, results are in fact very similar to those in the smaller sample with the narrower definition, independent of whether the country of origin is defined based on the mother, the father, or the average (columns 4-6). Including both parents’ cultures simultaneously also again yields very similar results (column 7).

In a few cases, the effect of a specific country of origin is identified from only a limited number of student observations, potentially introducing substantial measurement error for these countries of origin. However, if we restrict the analysis to cases where at least 50 students are observed from each country of origin - which reduces the number of countries of origin from 58 to 46 - results remain virtually unaffected (column 8). ${ }^{24}$

Selective migration. Finally, we investigate whether several possible dimensions of selective migration pose a threat to identification in our migrant analysis. As a start, we showed that neither economic conditions in the home country nor socio-economic differences in family background drive the estimates of cultural impacts (Table 3, column 8). Another straightforward way to address potential bias from fundamental background differences is to include fixed effects for the origin continent of the migrant students. Column 1 of Table 7 shows that the effects get slightly stronger when variation across continents of origin is removed. This analysis

24 This robustness analysis drops the following countries of origin: Bangladesh (17 observations), Canada (1), Chile (47), Finland (2), Georgia (3), Indonesia (27), Kazakhstan (34), Lithuania (3), Moldova (11), Nigeria (4), Saudi Arabia (8), and Thailand (20). 
also indicates that results are not driven by any geographical clustering of patience by continent or by (exogenous) outstanding performance of any specific group of migrants such as students from Asia, Europe, or Latin America.

Another concern is that migrants may be differentially selected from their respective countries of origin. It is well known that migration is a selective process (e.g., Borjas (1987); Grogger and Hanson (2011)). If the selectivity of migrants were the same for the different countries of origin that send migrants to a specific residence country, such migrant selectivity would not bias the migrant analysis. But, if there was differential migrant selectivity that is correlated with average cultural traits of the sending countries, bias could be introduced. This type of selection bias should be more severe for countries of origin with higher variance in cultural traits. However, controlling for the standard deviations of the two cultural measures within the country of origin does not affect the qualitative results, and neither of the two standard deviations enters the model significantly (column 2).

Another way to gauge the relevance of differentially selective migration is to take into account the geographical and cultural distance between the sending and the receiving countries. A general pattern in the migration literature is that migrants from neighboring countries may be less positively selected than migrants from more distant countries (see Hanushek, Ruhose, and Woessmann (2017) for evidence from the United States), possibly because fewer hurdles have to be overcome. Controlling for the geographical distance between migrants’ country of origin and residence country (using the distance measures from Mayer and Zignago (2011)) does not change our qualitative results (column 3). Similarly, our main findings are robust to controlling for the cultural distance defined as the difference in patience and risk-taking between migrant students' country of origin and residence country (column 5). While the main effects of both cultural distances do not enter the model significantly, there is a significant interaction for risktaking: The negative impact of risk-taking attenuates as cultural distance increases.

We also employ one direct measure of the differential selectivity of migrants based on their educational attainment. For each pair of sending and receiving countries, we compare the educational attainment of migrants in the residence country to the educational attainment of the populations of their respective countries of origin. We then measure migrant selectivity as the percentile of the country-of-origin distribution of educational attainment from which the average migrant in each residence country comes. Hanushek, Ruhose, and Woessmann (2017) produced 
this measure for immigrants into the United States, and we extend that analysis to the full matrix of origin and residence countries with available data. Migrant selectivity thus measured is indeed positively associated with student achievement (column 7), but accounting for this differential selectivity does not affect our estimates of the impact of patience and risk-taking.

\section{Channels of Impact}

Our analysis has established robust relationships between the two cultural factors and student achievement without direct reference to underlying mechanisms. This section investigates potential channels through which the relationships might operate. In the context of the canonical human capital production function, cultural traits may influence student achievement through proximate inputs - family inputs, school inputs, and institutional inputs as well as the overall productivity with which inputs are transformed into student achievement (section 2.2). In order to shed light on potential mechanisms, we consider how patience and risktaking relate to these major categories of proximate inputs. ${ }^{25}$

The starting point is developing composite measures of the three categories of proximate inputs. Building on the typical analysis of international educational production functions found in Woessmann (2016b), we run a pooled cross-country regression of PISA math scores on our full set of control variables. We then use the coefficient estimates on the individual variables in the model to aggregate them into family, school, and institutional factors. ${ }^{26}$ That is, for each input category, we calculate a linear combination as the sum of the products of the individual variables times their respective coefficients. We finally collapse the three combined input factors, as well as the residual of the achievement regression, to the country level.

To investigate the potential channels through which the time preferences operate, we regress the resulting four country-level variables on the two cultural traits, patience and risk-taking (Table 8). Focusing on the top half of the table, patience is positively associated with all four input components, although the association with institutional inputs is not quite significant at the

\footnotetext{
${ }^{25}$ Note that the analysis of channels is not meaningful for the migrant analysis. Migrants are not exposed to the school and institutional environment of the country that defines their cultural origin.

${ }^{26}$ We map the control variables (see section 3.1) into the three input vectors as follows: family inputs: gender, age, migration status, parental education, parental occupation, books at home, computer at home, language spoken at home, and GDP per capita (capturing overall economic wellbeing in the country); school inputs: school location, school size, share of fully certified teachers, and shortage of educational material; institutional inputs: share of privately managed schools, share of government funding at school, central exit exams, and school autonomy.
} 
10 percent level. The association and explained variance are strongest for family inputs (column 1) followed by the residual (column 4). The residual factor has the character of total factor productivity, combining any unmeasured components of the input factors with the effectiveness with which inputs are transformed into outputs. Similarly, risk-taking is negatively correlated with all four input components, although only significantly so for family inputs and the residual.

The aggregation of the individual proximate input variables uses coefficient estimates from an education production function that may be biased by the omission of the deeper cultural variables. Because individual coefficient estimates will be more biased for variables that are more strongly correlated with the cultural measures, the presented estimates serve as an upper bound for the cultural relationships. Alternatively, estimating the first step of the aggregation analysis including controls for the two cultural measures may serve as a lower bound, as the cultural measures take out important parts of the variation in the proximate inputs. ${ }^{27}$ As shown in the lower part of Table 8, the lower-bound procedure yields similar qualitative results of significant positive associations of patience with family and school inputs and a significant negative association of risk-taking with family inputs, only with expectedly smaller magnitudes. Interestingly, none of the other GPS cultural measures (positive reciprocity, negative reciprocity, altruism, and trust) are significantly related to any of the input factors (not shown).

Put together, these results are consistent with different input components of the education production function playing a role as channels through which the two intertemporal cultural traits affect student achievement. Of course, this analysis is inherently descriptive and should not be interpreted as a causal mediation analysis. At the same time, the observed patterns appear intuitive and highlight that the proximate inputs - and particularly family inputs and residual productivity - may operate as channels through which fundamental cultural traits affect student achievement. It is also interesting that the cultural traits have such limited association with institutional factors. Prior analyses have highlighted the importance of institutional factors in explaining cross-country achievement differences (Hanushek and Woessmann (2011); Woessmann (2016b)), implying that changing institutions may be a way for nations wishing to improve their schools to break out of cultural constraints.

\footnotetext{
${ }^{27}$ By construction, the input coefficients estimated in the lower-bound analysis are unaffected by the cultural factors, and the coefficients and the $R^{2}$ for the residual category are zero.
} 


\section{Conclusions}

International differences in student achievement are at the forefront of education policy debates, but the deeper reasons for why students in some countries perform better than in others are not well understood. While cultural differences across countries have standardly been discussed as potential confounding factors in cross-country analyses of student achievement, we explicitly investigate deep cultural factors as potential determinants of student learning. We focus on patience and risk-taking - the two cultural traits that reflect the intertemporal and risky nature of educational decisions - and combine international student achievement data from PISA with newly available data on cultural traits from the Global Preference Survey.

In our cross-country analysis, patience is strongly positively and risk-taking negatively associated with student achievement. Importantly, ignoring the interrelatedness between the two cultural traits leads to a substantial underestimation of both effects.

These results are confirmed in an identification strategy that compares migrant students from different country-of-origin cultures observed in the same residence country, eliminating any potential residence-country confounders. Results are robust in a series of sensitivity checks. In a final descriptive analysis, we show that culture likely influences national educational achievement by affecting several proximate inputs of the education production function, in particular family inputs and residual productivity.

Taking an international perspective in studying the factors that influence student achievement comes with both advantages and challenges. The interest of this paper is to understand the relationship between culture and student achievement across countries, and the documented strength of the culture-achievement nexus indicates the first-order nature of this question. However, identifying causal effects in international data is particularly challenging because of the multitude of potential factors influencing student achievement. Our migrant analysis, together with a series of robustness analyses, are entirely consistent with the conclusions from the cross-country analysis. Nonetheless, while addressing the most significant threats to identification of cultural impacts, other threats may remain. At the same time, it seems quite unlikely that any remaining bias would operate to eliminate the extraordinarily strong impacts of culture that we estimate. 


\section{References}

Abramitzky, Ran, Leah Boustan (2017). Immigration in American Economic History. Journal of Economic Literature 55 (4): 1311-1345.

Akyol, Ș. Pelin, Kala Krishna, Jinwen Wang (2018). Taking PISA Seriously: How Accurate Are Low Stakes Exams? NBER Working Paper 24930. Cambridge, MA: National Bureau of Economic Research (August).

Alan, Sule, Teodora Boneva, Seda Ertac (2019). Ever Failed, Try Again, Succeed Better: Results from a Randomized Educational Intervention on Grit. Quarterly Journal of Economics 134 (3): 1121-1162.

Alan, Sule, Seda Ertac (2018). Fostering Patience in the Classroom: Results from Randomized Educational Intervention. Journal of Political Economy 126 (5): 1865-1911.

Alesina, Alberto, Paola Giuliano (2014). Family Ties. In Handbook of Economic Growth, Vol. 2, edited by Philippe Aghion, Steven N. Durlauf. Amsterdam: North Holland: 177-215.

Alesina, Alberto, Paola Giuliano (2015). Culture and Institutions. Journal of Economic Literature 53 (4): 898-944.

Almlund, Mathilde, Angela L. Duckworth, James Heckman, Tim Kautz (2011). Personality Psychology and Economics. In Handbook of the Economics of Education, Vol. 4, edited by Eric A. Hanushek, Stephen Machin, Ludger Woessmann. Amsterdam: North Holland: 1-181.

Andreoni, James, Charles Sprenger (2012). Risk Preferences Are Not Time Preferences. American Economic Review 102 (7): 3357-3376.

Andreoni, James, Charles Sprenger (2015). Risk Preferences Are Not Time Preferences: Reply. American Economic Review 105 (7): 2287-2293.

Balart, Pau, Matthijs Oosterveen, Dinand Webbink (2018). Test Scores, Noncognitive Skills and Economic Growth. Economics of Education Review 63: 134-153.

Becker, Gary S. (1964). Human Capital: A Theoretical and Empirical Analysis, with Special Reference to Education. New York, NY: National Bureau of Economic Research.

Ben-Porath, Yoram (1967). The Production of Human Capital and the Life Cycle of Earnings. Journal of Political Economy 75 (4): 352-365.

Ben-Porath, Yoram (1970). The Production of Human Capital over Time. In Education, Income and Human Capital, edited by W. Lee Hansen. New York: National Bureau of Economic Research: 129-147.

Benzoni, Luca, Olena Chyruk (2015). The Value and Risk of Human Capital. Annual Review of Financial Economics 7 (1): 179-200.

Bisin, Alberto, Thierry Verdier (2011). The Economics of Cultural Transmission and Socialization. In Handbook of Social Economics, edited by Jess Benhabib, Alberto Bisin, Matthew O. Jackson. Amsterdam: North-Holland: 339-416.

Borghans, Lex, Trudie Schils (2012). The Leaning Tower of Pisa: Decomposing Achievement Test Scores into Cognitive and Noncognitive Components. Mimeo. 
Borjas, George J. (1987). Self-Selection and the Earnings of Immigrants. American Economic Review 77 (4): 531-553.

Brown, Jeffrey, Chichun Fang, Francisco Gomes (2012). Risk and Returns to Education. NBER Working Paper No. 18300. Cambridge, MA: National Bureau of Economic Research (August).

Carroll, Christopher D., Byung-Kun Rhee, Changyong Rhee (1994). Are There Cultural Effects on Saving? Some Cross-Sectional Evidence*. Quarterly Journal of Economics 109 (3): 685699.

Castillo, Marco, Jeffrey L. Jordan, Ragan Petrie (2019). Discount Rates of Children and High School Graduation. Economic Journal 129 (619): 1153-1181.

Chetty, Raj, David Grusky, Maximilian Hell, Nathaniel Hendren, Robert Manduca, Jimmy Narang (2017). The Fading American Dream: Trends in Absolute Income Mobility since 1940. Science 356 (6336): 398-406.

Cheung, Stephen L. (2015). Comment on "Risk Preferences Are Not Time Preferences": On the Elicitation of Time Preference under Conditions of Risk. American Economic Review 105 (7): 2242-2260.

Cordero, Jose M., Cristina Polo, Daniel Santín, Rosa Simancas (2018). Efficiency Measurement and Cross-Country Differences among Schools: A Robust Conditional Nonparametric Analysis. Economic Modelling 74: 45-60.

Cunha, Flavio, James J. Heckman, Susanne M. Schennach (2010). Estimating the Technology of Cognitive and Noncognitive Skill Formation. Econometrica 78 (3): 883-931.

Dohmen, Thomas, Benjamin Enke, Armin Falk, David Huffman, Uwe Sunde (2019). Patience and Comparative Development. Mimeo.

Dohmen, Thomas, Armin Falk, David Huffman, Uwe Sunde (2010). Are Risk Aversion and Impatience Related to Cognitive Ability? American Economic Review 100 (3): 1238-1260.

Dohmen, Thomas, Armin Falk, David Huffman, Uwe Sunde (2018). On the Relationship between Cognitive Ability and Risk Preference. Journal of Economic Perspectives 32 (2): 115-134.

Duckworth, Angela L., Christopher Peterson, Michael D. Matthews, Dennis R. Kelly (2007). Grit: Perseverance and Passion for Long-Term Goals. Journal of Personality and Social Psychology 92 (6): 1087-1101.

Epper, Thomas, Helga Fehr-Duda (2015). Comment on "Risk Preferences Are Not Time Preferences": Balancing on a Budget Line. American Economic Review 105 (7): 2261-2271.

Falk, Armin, Anke Becker, Thomas Dohmen, Benjamin Enke, David Huffman, Uwe Sunde (2018). Global Evidence on Economic Preferences. Quarterly Journal of Economics 133 (4): 1645-1692.

Falk, Armin, Anke Becker, Thomas Dohmen, David Huffman, Uwe Sunde (2016). The Preference Survey Module: A Validated Instrument for Measuring Risk, Time, and Social Preferences. IZA Discussion Paper 9674. Bonn: Institute for the Study of Labor. 
Fernández, Raquel, Alessandra Fogli (2009). Culture: An Empirical Investigation of Beliefs, Work, and Fertility. American Economic Journal: Macroeconomics 1 (1): 146-77.

Figlio, David, Paola Giuliano, Umut Özek, Paola Sapienza (2019). Long-Term Orientation and Educational Performance. American Economic Journal: Economic Policy 11 (4): 272-309.

Freeman, Richard B. (1999). The Economics of Crime. In Handbook of Labor Economics, Vol. 3C, edited by Orley Ashenfelter, David Card. Amsterdam: North-Holland: 3529-3571.

Galor, Oded, Ömer Özak (2016). The Agricultural Origins of Time Preference. American Economic Review 106 (10): 3064-3103.

Giuliano, Paola (2007). Living Arrangements in Western Europe: Does Cultural Origin Matter? Journal of the European Economic Association 5 (5): 927-952.

Gneezy, Uri, John A. List, Jeffrey A. Livingston, Xiangdong Qin, Sally Sadoff, Yang Xu (2019). Measuring Success in Education: The Role of Effort on the Test Itself. American Economic Review: Insights 1 (3): 291-308.

Golsteyn, Bart H.H., Hans Grönqvist, Lena Lindahl (2014). Adolescent Time Preferences Predict Lifetime Outcomes. Economic Journal 124 (580): F739-F761.

Grogger, Jeffrey, Gordon H. Hanson (2011). Income Maximization and the Selection and Sorting of International Migrants. Journal of Development Economics 95 (1): 42-57.

Groot, Wim, Hessel Oosterbeek (1992). Optimal Investment in Human Capital under Uncertainty Economics of Education Review 11 (1): 41-49.

Guiso, Luigi, Paola Sapienza, Luigi Zingales (2006). Does Culture Affect Economic Outcomes? Journal of Economic Perspectives 20 (2): 23-48.

Halevy, Yoram (2008). Strotz Meets Allais: Diminishing Impatience and the Certainty Effect. American Economic Review 98 (3): 1145-1162.

Hanushek, Eric A. (1986). The Economics of Schooling: Production and Efficiency in Public Schools. Journal of Economic Literature 24 (3): 1141-1177.

Hanushek, Eric A., Marc Piopiunik, Simon Wiederhold (2019). The Value of Smarter Teachers: International Evidence on Teacher Cognitive Skills and Student Performance. Journal of Human Resources 54 (4): 857-899.

Hanushek, Eric A., Jens Ruhose, Ludger Woessmann (2017). Knowledge Capital and Aggregate Income Differences: Development Accounting for U.S. States. American Economic Journal: Macroeconomics 9 (4): 184-224.

Hanushek, Eric A., Guido Schwerdt, Simon Wiederhold, Ludger Woessmann (2015). Returns to Skills around the World: Evidence from PIAAC. European Economic Review 73: 103-130.

Hanushek, Eric A., Guido Schwerdt, Simon Wiederhold, Ludger Woessmann (2017). Coping with Change: International Differences in the Returns to Skills. Economic Letters 153: 15-19.

Hanushek, Eric A., Ludger Woessmann (2008). The Role of Cognitive Skills in Economic Development. Journal of Economic Literature 46 (3): 607-668.

Hanushek, Eric A., Ludger Woessmann (2011). The Economics of International Differences in Educational Achievement. In Handbook of the Economics of Education, Vol. 3, edited by 
Eric A. Hanushek, Stephen Machin, Ludger Woessmann. Amsterdam: North Holland: 89200.

Hanushek, Eric A., Ludger Woessmann (2012). Do Better Schools Lead to More Growth? Cognitive Skills, Economic Outcomes, and Causation. Journal of Economic Growth 17 (4): 267-321.

Hanushek, Eric A., Ludger Woessmann (2015). The Knowledge Capital of Nations: Education and the Economics of Growth. Cambridge, MA: MIT Press.

Hartog, Joop, Luis Diaz-Serrano (2007). Earnings Risk and Demand for Higher Education: A Cross-Section Test for Spain. Journal of Applied Economics 10 (1): 1-28.

Hartog, Joop, Luis Diaz-Serrano (2014). Schooling as a Risky Investment: A Survey of Theory and Evidence. Foundations and Trends in Microeconomics 9 (3-4): 159-331.

Heckman, James J. (1976). A Life-Cycle Model of Earnings, Learning, and Consumption. Journal of Political Economy 84 (4): S11-S44.

Hofstede, Geert H. (1991). Cultures and Organizations: Software of the Mind. London: McGraw-Hill.

Hofstede, Geert H., Gert Jan Hofstede, Michael Minkov (2010). Cultures and Organizations: Software of the Mind: Intercultural Cooperation and Its Importance for Survival. 3rd Ed. New York: McGraw-Hill.

Kim, Hong-Kyun (2001). Is There a Crowding-out Effect between School Expenditure and Mother's Child Care Time? Economics of Education Review 20 (1): 71-80.

Koerselman, Kristian, Roope Uusitalo (2014). The Risk and Return of Human Capital Investments. Labour Economics 30: 154-163.

Lavecchia, Adam M., Heidi Liu, Philip Oreopoulos (2016). Behavioral Economics of Education: Progress and Possibilities. In Handbook of the Economics of Education, Vol. 5, edited by Eric A. Hanushek, Stephen Machin, Ludger Woessmann. Amsterdam: North Holland: 1-74.

Levhari, David, Yoram Weiss (1974). The Effect of Risk on the Investment in Human Capital. American Economic Review 64 (6): 950-963.

Mendez, Ildefonso (2015). The Effect of the Intergenerational Transmission of Noncognitive Skills on Student Performance. Economics of Education Review 46: 78-97.

Mayer, Thierry, Soledad Zignago (2011). Notes on CEPII's Distances Measures: The GeoDist Database. CEPII Working Paper 2011-25. http://www.cepii.fr/CEPII/en/bdd_modele/presentation.asp?id=6.

Miao, Bin, Songfa Zhong (2015). Comment on "Risk Preferences Are Not Time Preferences": Separating Risk and Time Preference. American Economic Review 105 (7): 2272-2286.

Mincer, Jacob (1958). Investment in Human Capital and Personal Income Distribution. Journal of Political Economy 66 (4): 281-302.

Mincer, Jacob (1974). Schooling, Experience, and Earnings. New York: NBER.

Mischel, Walter, Yuichi Shoda, Monica L. Rodriguez (1989). Delay of Gratification in Children. Science 244 (4907): 933-938. 
Moffitt, Terrie E., Louise Arseneault, Daniel Belsky, Nigel Dickson, Robert J. Hancox, HonaLee Harrington, Renate Houts, Richie Poulton, Brent W. Roberts, Stephen Ross, Malcolm R. Sears, W. Murray Thomson, Avshalom Caspi (2011). A Gradient of Childhood Self-Control Predicts Health, Wealth, and Public Safety. Proceedings of the National Academy of Sciences 108 (7): 2693-2698.

OECD (2019). PISA 2018 Results (Volume I). Paris: OECD Publishing.

Palacios-Huerta, Ignacio (2003). An Empirical Analysis of the Risk Properties of Human Capital Returns. American Economic Review 93 (3): 948-964.

Potrafke, Niklas (2019). Risk Aversion, Patience and Intelligence: Evidence Based on Macro Data. Economic Letters 178: 116-120.

Rosen, Sherwin (1976). A Theory of Life Earnings. Journal of Political Economy 84 (4): S45S67.

Sutter, Matthias, Martin G. Kocher, Daniela Glätzle-Rützler, Stefan T. Trautmann (2013). Impatience and Uncertainty: Experimental Decisions Predict Adolescents' Field Behavior. American Economic Review 103 (1): 510-531.

Todd, Petra E., Kenneth I. Wolpin (2003). On the Specification and Estimation of the Production Function for Cognitive Achievement. Economic Journal 113 (485): F3-33.

Weiss, Yoram (1972). The Risk Element in Occupational and Educational Choices. Journal of Political Economy 80 (6): 1203-1213.

Woessmann, Ludger (2016a). The Economic Case for Education. Education Economics 24 (1): 3-32.

Woessmann, Ludger (2016b). The Importance of School Systems: Evidence from International Differences in Student Achievement. Journal of Economic Perspectives 30 (3): 3-32.

Zamarro, Gema, Collin Hitt, Ildefonso Mendez (2019). When Students Don’t Care: Reexamining International Differences in Achievement and Student Effort. Journal of Human Capital 13 (4): 519-552. 
Table A1: Countries in the different analyses

\begin{tabular}{|c|c|c|c|c|c|}
\hline & \multirow[b]{2}{*}{$\begin{array}{l}\text { PISA } \\
(1)\end{array}$} & \multirow[b]{2}{*}{$\begin{array}{l}\text { GPS } \\
(2)\end{array}$} & \multirow{2}{*}{$\begin{array}{l}\text { Cross-country } \\
\text { analysis } \\
\text { (3) }\end{array}$} & \multicolumn{2}{|c|}{ Migrant analysis } \\
\hline & & & & $\begin{array}{c}\text { Residence country } \\
\text { (4) }\end{array}$ & $\begin{array}{l}\text { Country of origin } \\
\text { (5) }\end{array}$ \\
\hline Afghanistan & & $\mathrm{x}$ & & & $\mathrm{X}$ \\
\hline Algeria & $\mathrm{x}$ & $\mathrm{x}$ & $\mathrm{x}$ & & \\
\hline Argentina & $\mathrm{x}$ & $\mathrm{x}$ & $\mathrm{x}$ & $\mathrm{x}$ & $\mathrm{x}$ \\
\hline Australia & $\mathrm{x}$ & $\mathrm{x}$ & $\mathrm{x}$ & $\mathrm{x}$ & $\mathrm{x}$ \\
\hline Austria & $\mathrm{x}$ & $\mathrm{x}$ & $\mathrm{x}$ & $\mathrm{x}$ & $\mathrm{x}$ \\
\hline Bangladesh & & $\mathrm{X}$ & & & $\mathrm{x}$ \\
\hline Belarus & $\mathrm{x}$ & & & $\mathrm{x}$ & \\
\hline Belgium & $\mathrm{x}$ & & & $\mathrm{x}$ & \\
\hline Bolivia & & $\mathrm{x}$ & & & $\mathrm{x}$ \\
\hline Bosnia Herzegovina & $\mathrm{x}$ & $\mathrm{x}$ & $\mathrm{x}$ & $\mathrm{x}$ & $\mathrm{x}$ \\
\hline Brazil & $\mathrm{x}$ & $\mathrm{X}$ & $\mathrm{x}$ & & $\mathrm{X}$ \\
\hline Brunei Darussalam & $\mathrm{x}$ & & & $\mathrm{X}$ & \\
\hline Canada & $\mathrm{x}$ & $\mathrm{x}$ & $\mathrm{x}$ & $\mathrm{x}$ & $\mathrm{x}$ \\
\hline Chile & $\mathrm{x}$ & $\mathrm{x}$ & $\mathrm{x}$ & & $\mathrm{x}$ \\
\hline China & & $\mathrm{X}$ & & & $\mathrm{x}$ \\
\hline Colombia & $\mathrm{X}$ & $\mathrm{X}$ & $\mathrm{X}$ & & $\mathrm{x}$ \\
\hline Costa Rica & $\mathrm{x}$ & $\mathrm{X}$ & $\mathrm{x}$ & $\mathrm{x}$ & \\
\hline Croatia & $\mathrm{x}$ & $\mathrm{x}$ & $\mathrm{x}$ & $\mathrm{x}$ & $\mathrm{x}$ \\
\hline Czech Republic & $\mathrm{x}$ & $\mathrm{x}$ & $\mathrm{x}$ & $\mathrm{x}$ & $\mathrm{x}$ \\
\hline Denmark & $\mathrm{x}$ & & & $\mathrm{x}$ & \\
\hline Dominican Republic & $\mathrm{x}$ & & & $\mathrm{x}$ & \\
\hline Egypt & & $\mathrm{x}$ & & & $\mathrm{x}$ \\
\hline Estonia & $\mathrm{x}$ & $\mathrm{x}$ & $\mathrm{x}$ & & $\mathrm{x}$ \\
\hline Finland & $\mathrm{x}$ & $\mathrm{x}$ & $\mathrm{x}$ & $\mathrm{x}$ & $\mathrm{x}$ \\
\hline France & $\mathrm{x}$ & $\mathrm{X}$ & $\mathrm{x}$ & & $\mathrm{x}$ \\
\hline Georgia & $\mathrm{x}$ & $\mathrm{x}$ & $\mathrm{x}$ & $\mathrm{X}$ & $\mathrm{x}$ \\
\hline Germany & $\mathrm{x}$ & $\mathrm{x}$ & $\mathrm{x}$ & $\mathrm{x}$ & $\mathrm{x}$ \\
\hline Greece & $\mathrm{x}$ & $\mathrm{x}$ & $\mathrm{x}$ & & $\mathrm{x}$ \\
\hline Haiti & & $\mathrm{x}$ & & & $\mathrm{x}$ \\
\hline Hong Kong & $\mathrm{x}$ & & & $\mathrm{x}$ & \\
\hline Hungary & $\mathrm{x}$ & $\mathrm{X}$ & $\mathrm{X}$ & & $\mathrm{x}$ \\
\hline India & & $\mathrm{x}$ & & & $\mathrm{x}$ \\
\hline Indonesia & $\mathrm{x}$ & $\mathrm{x}$ & $\mathrm{x}$ & $\mathrm{x}$ & $\mathrm{x}$ \\
\hline Iran & & $\mathrm{x}$ & & & $\mathrm{x}$ \\
\hline Iraq & & $\mathrm{x}$ & & & $\mathrm{x}$ \\
\hline Ireland & $\mathrm{x}$ & & & $x$ & \\
\hline Israel & $\mathrm{x}$ & $\mathrm{x}$ & $\mathrm{x}$ & $\mathrm{x}$ & \\
\hline Italy & $\mathrm{x}$ & $\mathrm{x}$ & $\mathrm{x}$ & & $\mathrm{x}$ \\
\hline Japan & $\mathrm{x}$ & $\mathrm{x}$ & $\mathrm{x}$ & & \\
\hline Jordan & $\mathrm{x}$ & $\mathrm{X}$ & $\mathrm{x}$ & $\mathrm{x}$ & $\mathrm{x}$ \\
\hline Kazakhstan & $\mathrm{x}$ & $\mathrm{x}$ & $\mathrm{x}$ & & $\mathrm{x}$ \\
\hline Kyrgyzstan & $\mathrm{x}$ & & & $\mathrm{x}$ & \\
\hline Latvia & $\mathrm{x}$ & & & $\mathrm{x}$ & \\
\hline Liechtenstein & $\mathrm{x}$ & & & $\mathrm{X}$ & \\
\hline Lithuania & $\mathrm{x}$ & $\mathrm{X}$ & $\mathrm{x}$ & & $\mathrm{x}$ \\
\hline Luxembourg & $\mathrm{x}$ & & & $\mathrm{x}$ & \\
\hline Масао & $\mathrm{x}$ & & & $\mathrm{x}$ & \\
\hline Mauritius & $\mathrm{x}$ & & & $\mathrm{x}$ & \\
\hline Mexico & $\mathrm{x}$ & $\mathrm{x}$ & $\mathrm{x}$ & $\mathrm{x}$ & \\
\hline Moldova & $\mathrm{x}$ & $\mathrm{x}$ & $\mathrm{x}$ & $\mathrm{x}$ & $\mathrm{x}$ \\
\hline Montenegro & $\mathrm{X}$ & & & $\mathrm{x}$ & \\
\hline
\end{tabular}

(continued on next page) 
Table A1 (continued)

\begin{tabular}{|c|c|c|c|c|c|}
\hline & \multirow[b]{2}{*}{$\begin{array}{l}\text { PISA } \\
(1)\end{array}$} & \multirow[b]{2}{*}{$\begin{array}{l}\text { GPS } \\
(2)\end{array}$} & \multirow{2}{*}{$\begin{array}{l}\text { Cross-country } \\
\text { analysis } \\
\text { (3) }\end{array}$} & \multicolumn{2}{|c|}{ Migrant analysis } \\
\hline & & & & $\begin{array}{c}\text { Residence country } \\
\text { (4) }\end{array}$ & $\begin{array}{l}\text { Country of origin } \\
\text { (5) }\end{array}$ \\
\hline Morocco & $\mathrm{X}$ & $\mathrm{X}$ & $\mathrm{x}$ & $\mathrm{x}$ & $\mathrm{x}$ \\
\hline Netherlands & $\mathrm{x}$ & $\mathrm{x}$ & $\mathrm{x}$ & $\mathrm{x}$ & $\mathrm{x}$ \\
\hline New Zealand & $\mathrm{x}$ & & & $\mathrm{x}$ & \\
\hline Nicaragua & & $\mathrm{X}$ & & & $\mathrm{x}$ \\
\hline Nigeria & & $\mathrm{x}$ & & & $\mathrm{x}$ \\
\hline North Macedonia & $\mathrm{X}$ & & & $\mathrm{x}$ & \\
\hline Norway & $\mathrm{x}$ & & & $\mathrm{x}$ & \\
\hline Pakistan & & $\mathrm{x}$ & & & $\mathrm{x}$ \\
\hline Panama & $\mathrm{x}$ & & & $\mathrm{x}$ & \\
\hline Peru & $\mathrm{X}$ & $\mathrm{X}$ & $\mathrm{x}$ & & \\
\hline Philippines & $\mathrm{x}$ & $\mathrm{x}$ & $\mathrm{x}$ & $\mathrm{x}$ & $\mathrm{x}$ \\
\hline Poland & $\mathrm{x}$ & $\mathrm{x}$ & $\mathrm{x}$ & & $\mathrm{x}$ \\
\hline Portugal & $\mathrm{x}$ & $\mathrm{x}$ & $\mathrm{x}$ & $\mathrm{x}$ & $\mathrm{x}$ \\
\hline Qatar & $\mathrm{x}$ & & & $\mathrm{x}$ & \\
\hline Romania & $\mathrm{x}$ & $\mathrm{x}$ & $\mathrm{x}$ & & $\mathrm{x}$ \\
\hline Russia & $\mathrm{x}$ & $\mathrm{X}$ & $\mathrm{X}$ & & $\mathrm{x}$ \\
\hline Saudi Arabia & $\mathrm{x}$ & $\mathrm{x}$ & $\mathrm{x}$ & $\mathrm{x}$ & $\mathrm{x}$ \\
\hline Serbia & $\mathrm{x}$ & $\mathrm{x}$ & $\mathrm{x}$ & & $\mathrm{x}$ \\
\hline Slovakia & $\mathrm{x}$ & & & $\mathrm{x}$ & \\
\hline Slovenia & $\mathrm{x}$ & & & $\mathrm{x}$ & \\
\hline South Africa & & $\mathrm{X}$ & & & $\mathrm{x}$ \\
\hline South Korea & $\mathrm{x}$ & $\mathrm{x}$ & $\mathrm{x}$ & $\mathrm{x}$ & $\mathrm{x}$ \\
\hline Spain & $\mathrm{x}$ & $\mathrm{x}$ & $\mathrm{x}$ & & $\mathrm{x}$ \\
\hline Suriname & & $\mathrm{x}$ & & & $\mathrm{x}$ \\
\hline Sweden & $\mathrm{x}$ & $\mathrm{x}$ & $\mathrm{x}$ & & $\mathrm{x}$ \\
\hline Switzerland & $\mathrm{X}$ & $\mathrm{X}$ & $\mathrm{X}$ & $\mathrm{x}$ & $\mathrm{X}$ \\
\hline Thailand & $\mathrm{x}$ & $\mathrm{X}$ & $\mathrm{x}$ & & $\mathrm{x}$ \\
\hline Turkey & $\mathrm{x}$ & $\mathrm{x}$ & $\mathrm{x}$ & $\mathrm{x}$ & $\mathrm{x}$ \\
\hline Ukraine & $\mathrm{x}$ & $\mathrm{x}$ & $\mathrm{x}$ & $\mathrm{x}$ & $\mathrm{x}$ \\
\hline United Arab Emirates & $\mathrm{x}$ & $\mathrm{x}$ & $\mathrm{x}$ & & $\mathrm{x}$ \\
\hline United Kingdom & $\mathrm{X}$ & $\mathrm{X}$ & $\mathrm{X}$ & $\mathrm{x}$ & $\mathrm{x}$ \\
\hline United States & $\mathrm{x}$ & $\mathrm{x}$ & $\mathrm{x}$ & & $\mathrm{x}$ \\
\hline Uruguay & $\mathrm{x}$ & & & $\mathrm{x}$ & \\
\hline Venezuela & & $\mathrm{x}$ & & & $\mathrm{x}$ \\
\hline Vietnam & $\mathrm{x}$ & $\mathrm{x}$ & $\mathrm{x}$ & & $\mathrm{x}$ \\
\hline Total: 86 countries & 71 & 64 & 49 & 48 & 58 \\
\hline
\end{tabular}

Notes: The structure of country inclusion in the different parts of our analysis is complex. Three countries are included only in the baseline analysis because they participated in PISA (and GPS) but do not have migrant students with country-of-origin information (for which there is GPS data) and no student from these countries is observed as a migrant student in another PISA country. Another three countries are included in the baseline analysis and (only) as residence countries in the migrant analysis because they participated in PISA (and GPS) and have migrant students from countries of origin with GPS data, but no student from these countries is observed as a migrant student in another PISA country. 23 countries are included in the baseline analysis and both as residence countries and as countries of origin in the migrant analysis. There is also the case of 20 countries that are included in the baseline analysis and (only) as countries of origin in the migrant analysis because they participated in PISA (and GPS) but do not have migrant students with country-of-origin information (for which there is GPS data), and students from these countries are observed as migrant students in other PISA countries. 22 countries are not included in the baseline analysis, but only as residence countries in the migrant analysis because they participated in PISA, but there is no GPS data for them; however, there is GPS data for the country of origin of some of the migrant students tested in these countries. Finally, 15 countries are included only as countries of origin in the migrant analysis; these countries did not participate in PISA themselves and therefore cannot be included in the baseline analysis or as residence countries in the migrant analysis, but there is GPS data for them and students originating from these countries are observed as migrant students in residence countries that did participate in PISA. 
Table A2: Descriptive statistics at the country level

\begin{tabular}{lcccc}
\hline & Mean & Std. dev. & Min & Max \\
& $(1)$ & $(2)$ & & \\
& & & $3)$ \\
\hline PISA scores & & 0.560 & 3.524 & 5.410 \\
Math & 4.520 & 0.531 & 3.579 & 5.415 \\
Science & 4.597 & 0.521 & 3.395 & 5.345 \\
Reading & 4.535 & & -0.555 & 0.946 \\
Preferences & & 0.384 & -0.746 & 0.789 \\
Patience & -0.003 & 0.241 & -1.094 & 0.558 \\
Risk-taking & 0.027 & 0.315 & -0.510 & 0.716 \\
Positive reciprocity & -0.016 & 0.308 & -0.923 & 0.679 \\
Negative reciprocity & 0.025 & 0.346 & -0.575 & 0.507 \\
Altruism & -0.022 & 0.249 & \\
Trust & -0.016 & & \\
\hline \hline
\end{tabular}

Notes: PISA scores: country means, pooled across all PISA waves 2000-2018, weighted by sampling probabilities. Preferences: country means of GPS preference data. Sample: 263 country-by-wave observations (reflecting 49 countries) contained in our baseline analysis of Table 1. Data sources: PISA international student achievement test, 2000-2018; Falk et al. (2018). 
Table A3: Country-level correlation of cultural measures

\begin{tabular}{|c|c|c|c|c|c|c|c|c|c|}
\hline & $\begin{array}{c}\text { Patience } \\
\text { (1) }\end{array}$ & $\begin{array}{c}\text { Risk-taking } \\
\text { (2) }\end{array}$ & $\begin{array}{l}\text { Positive } \\
\text { reciprocity } \\
\text { (3) }\end{array}$ & $\begin{array}{l}\text { Negative } \\
\text { reciprocity } \\
\text { (4) }\end{array}$ & $\begin{array}{l}\text { Altruism } \\
\text { (5) }\end{array}$ & $\begin{array}{l}\text { Trust } \\
\text { (6) }\end{array}$ & $\begin{array}{c}\text { WVS } \\
\text { long-term } \\
\text { orientation } \\
\text { (7) }\end{array}$ & $\begin{array}{c}\text { WVS } \\
\text { risk-taking } \\
\text { (8) }\end{array}$ & $\begin{array}{c}\text { Hofstede } \\
\text { long-term } \\
\text { orientation } \\
\text { (9) }\end{array}$ \\
\hline Risk-taking & $\begin{array}{c}0.358 \\
(0.012)\end{array}$ & & & & & & & & \\
\hline Positive reciprocity & $\begin{array}{l}-0.154 \\
(0.291)\end{array}$ & $\begin{array}{l}-0.148 \\
(0.310)\end{array}$ & & & & & & & \\
\hline Negative reciprocity & $\begin{array}{c}0.236 \\
(0.103)\end{array}$ & $\begin{array}{c}0.334 \\
(0.019)\end{array}$ & $\begin{array}{l}-0.277 \\
(0.054)\end{array}$ & & & & & & \\
\hline Altruism & $\begin{array}{l}-0.051 \\
(0.728)\end{array}$ & $\begin{array}{c}0.110 \\
(0.451)\end{array}$ & $\begin{array}{c}0.699 \\
(0.000)\end{array}$ & $\begin{array}{l}-0.200 \\
(0.168)\end{array}$ & & & & & \\
\hline Trust & $\begin{array}{c}0.197 \\
(0.176)\end{array}$ & $\begin{array}{c}0.162 \\
(0.265)\end{array}$ & $\begin{array}{c}0.259 \\
(0.072)\end{array}$ & $\begin{array}{l}-0.025 \\
(0.864)\end{array}$ & $\begin{array}{c}0.207 \\
(0.153)\end{array}$ & & & & \\
\hline WVS long-term orientation & $\begin{array}{l}-0.060 \\
(0.700)\end{array}$ & $\begin{array}{l}-0.334 \\
(0.027)\end{array}$ & $\begin{array}{l}-0.195 \\
(0.204)\end{array}$ & $\begin{array}{c}0.057 \\
(0.715)\end{array}$ & $\begin{array}{l}-0.163 \\
(0.290)\end{array}$ & $\begin{array}{c}-0.104 \\
(0.500)\end{array}$ & & & \\
\hline WVS risk-taking & $\begin{array}{l}-0.260 \\
(0.125)\end{array}$ & $\begin{array}{c}0.239 \\
(0.160)\end{array}$ & $\begin{array}{c}0.117 \\
(0.498)\end{array}$ & $\begin{array}{c}0.138 \\
(0.423)\end{array}$ & $\begin{array}{c}0.269 \\
(0.112)\end{array}$ & $\begin{array}{c}0.313 \\
(0.063)\end{array}$ & $\begin{array}{l}-0.079 \\
(0.646)\end{array}$ & & \\
\hline Hofstede long-term orientation & $\begin{array}{c}0.247 \\
(0.115)\end{array}$ & $\begin{array}{l}-0.219 \\
(0.164)\end{array}$ & $\begin{array}{l}-0.326 \\
(0.035)\end{array}$ & $\begin{array}{c}0.321 \\
(0.038)\end{array}$ & $\begin{array}{l}-0.256 \\
(0.101)\end{array}$ & $\begin{array}{l}-0.246 \\
(0.116)\end{array}$ & $\begin{array}{c}0.609 \\
(0.000)\end{array}$ & $\begin{array}{l}-0.310 \\
(0.084)\end{array}$ & \\
\hline Hofstede uncertainty avoidance & $\begin{array}{c}-0.558 \\
(0.000)\end{array}$ & $\begin{array}{l}-0.302 \\
(0.046)\end{array}$ & $\begin{array}{l}-0.055 \\
(0.721)\end{array}$ & $\begin{array}{c}0.123 \\
(0.426)\end{array}$ & $\begin{array}{l}-0.185 \\
(0.229)\end{array}$ & $\begin{array}{l}-0.527 \\
(0.000)\end{array}$ & $\begin{array}{c}0.006 \\
(0.971)\end{array}$ & $\begin{array}{l}-0.093 \\
(0.611)\end{array}$ & $\begin{array}{c}0.024 \\
(0.880)\end{array}$ \\
\hline
\end{tabular}

Notes: Correlation coefficients; $p$-values in parentheses. Sample: 49 countries contained in our baseline analysis. Number of country observations: 49 among GPS measures, 44 between GPS and Hofstede uncertainty avoidance or WVS long-term orientation, 42 between GPS and Hofstede uncertainty avoidance and among Hofstede measures, 36 between GPS and WVS risk-taking and among WVS measures, and 32 between WVS and Hofstede measures. Data sources: Falk et al. (2018); World Values Survey (WVS); Hofstede, Hofstede, and Minkov (2010). 
Table A4: Alternative WVS and Hofstede measures of cultural traits

\begin{tabular}{|c|c|c|c|c|}
\hline & \multicolumn{2}{|c|}{ Baseline analysis } & \multicolumn{2}{|c|}{ Migrant analysis } \\
\hline & $(1)$ & $(2)$ & (3) & (4) \\
\hline WVS long-term orientation & $\begin{array}{c}0.171^{*} \\
(0.091)\end{array}$ & & $\begin{array}{c}0.176^{* * *} \\
(0.030)\end{array}$ & \\
\hline WVS risk-taking & $\begin{array}{c}-0.245^{* * *} \\
(0.075)\end{array}$ & & $\begin{array}{c}-0.120^{* * *} \\
(0.029)\end{array}$ & \\
\hline Hofstede long-term orientation & & $\begin{array}{c}0.339^{* * *} \\
(0.054)\end{array}$ & & $\begin{array}{c}0.206^{* * *} \\
(0.029)\end{array}$ \\
\hline Hofstede uncertainty avoidance & & $\begin{array}{l}-0.101 \\
(0.068)\end{array}$ & & $\begin{array}{c}-0.092^{* * *} \\
(0.031)\end{array}$ \\
\hline Residence-country by wave fixed effects & No & No & Yes & Yes \\
\hline Baseline controls & Yes & Yes & Yes & Yes \\
\hline Observations & $1,531,302$ & $1,839,052$ & 62,834 & 74,892 \\
\hline Countries of origin & & & 40 & 48 \\
\hline Residence countries & 36 & 42 & 44 & 48 \\
\hline$R^{2}$ & 0.109 & 0.134 & 0.246 & 0.250 \\
\hline
\end{tabular}

Notes: Dependent variable: PISA math test score, col. 1-2: waves 2000-2018, col. 3-4: 2003-2018. Least squares regressions. Col. 1-2: weighted by students' sampling probability. Col. 3-4: sample: students with both parents not born in the country where the student attends school; indicated cultural variables refer to country of origin. WVS and Hofstede measures $z$-standardized at the country level. Baseline control variables: col. 1-2: student gender, age, and migration status; imputation dummies; and wave fixed effects; col. 3-4: student gender, age, dummy for OECD country of origin, imputation dummies. Robust standard errors adjusted for clustering at the country level in parentheses. Significance level: ${ }^{* * *} 1$ percent, ${ }^{* *} 5$ percent, ${ }^{*} 10$ percent. Data sources: PISA international student achievement test, 2000-2018; World Values Survey (WVS); Hofstede, Hofstede, and Minkov (2010). 
Table 1: Culture and student achievement across countries: The intertwined roles of patience and risk-taking

\begin{tabular}{|c|c|c|c|c|c|c|c|c|}
\hline & \multicolumn{4}{|c|}{ PISA 2015} & \multicolumn{2}{|c|}{ PISA 2000-2018 } & \multicolumn{2}{|c|}{ Extended controls } \\
\hline & (1) & (2) & (3) & (4) & (5) & (6) & $\begin{array}{c}\text { PISA } 2015 \\
\text { (7) }\end{array}$ & $\begin{array}{c}\text { PISA 2000-2018 } \\
\text { (8) }\end{array}$ \\
\hline Patience & $\begin{array}{c}0.794^{* * *} \\
(0.125)\end{array}$ & & $\begin{array}{l}1.090^{* * *} \\
(0.129)\end{array}$ & $\begin{array}{c}1.078^{* * *} \\
(0.113)\end{array}$ & $\begin{array}{c}1.226^{* * *} \\
(0.132)\end{array}$ & $\begin{array}{l}1.186^{* * *} \\
(0.123)\end{array}$ & $\begin{array}{c}0.763^{* * *} \\
(0.175)\end{array}$ & $\begin{array}{c}0.748^{* * *} \\
(0.192)\end{array}$ \\
\hline Risk-taking & & $\begin{array}{l}-0.361 \\
(0.340)\end{array}$ & $\begin{array}{c}-1.226^{* * *} \\
(0.220)\end{array}$ & $\begin{array}{c}-1.292^{* * *} \\
(0.209)\end{array}$ & $\begin{array}{c}-1.241^{* * *} \\
(0.184)\end{array}$ & $\begin{array}{c}-1.314^{* * *} \\
(0.219)\end{array}$ & $\begin{array}{c}-0.912^{* * *} \\
(0.178)\end{array}$ & $\begin{array}{c}-0.835^{* * *} \\
(0.147)\end{array}$ \\
\hline Positive reciprocity & & & & $\begin{array}{c}0.107 \\
(0.261)\end{array}$ & & $\begin{array}{c}0.036 \\
(0.226)\end{array}$ & & \\
\hline Negative reciprocity & & & & $\begin{array}{l}0.289^{*} \\
(0.158)\end{array}$ & & $\begin{array}{l}0.315^{*} \\
(0.175)\end{array}$ & & \\
\hline Altruism & & & & $\begin{array}{l}-0.235 \\
(0.186)\end{array}$ & & $\begin{array}{l}-0.230 \\
(0.188)\end{array}$ & & \\
\hline Trust & & & & $\begin{array}{l}-0.173 \\
(0.159)\end{array}$ & & $\begin{array}{l}-0.048 \\
(0.152)\end{array}$ & & \\
\hline Baseline controls & Yes & Yes & Yes & Yes & Yes & Yes & Yes & Yes \\
\hline Extended controls & No & No & No & No & No & No & Yes & Yes \\
\hline Observations & 319,997 & 319,997 & 319,997 & 319,997 & $1,992,276$ & $1,992,276$ & 319,997 & $1,992,276$ \\
\hline Countries & 41 & 41 & 41 & 41 & 49 & 49 & 41 & 49 \\
\hline$R^{2}$ & 0.102 & 0.013 & 0.157 & 0.171 & 0.198 & 0.213 & 0.329 & 0.368 \\
\hline
\end{tabular}

Notes: Dependent variable: PISA math test score. Least squares regression weighted by students' sampling probability. Baseline control variables: student gender, age, and migration status; imputation dummies; and wave fixed effects. Extended control variables: baseline controls plus parental education, parental occupation, books at home, computer at home, language spoken at home; school location, school size, share of fully certified teachers at school, shortage of educational material; country's GDP per capita, share of privately managed schools, share of government funding at school, central exit exams, and school autonomy. Robust standard errors adjusted for clustering at the country level in parentheses. Significance level: ${ }^{* * *} 1$ percent, ${ }^{* *} 5$ percent, ${ }^{*} 10$ percent. Data sources: PISA international student achievement test, 2000-2018; Falk et al. (2018). 
Table 2: Patience, risk-taking, and student achievement across countries: Subsamples, additional subjects, and test-taking effort

\begin{tabular}{|c|c|c|c|c|c|c|c|c|}
\hline & \multicolumn{2}{|c|}{ Students’ migrant status } & \multicolumn{2}{|c|}{ Country subsamples } & \multicolumn{2}{|c|}{ Additional subjects } & \multicolumn{2}{|c|}{ Test-taking effort } \\
\hline & $\begin{array}{c}\text { Natives } \\
\text { (1) }\end{array}$ & $\begin{array}{l}\text { Migrants } \\
\text { (2) }\end{array}$ & $\begin{array}{c}\text { OECD } \\
(3)\end{array}$ & $\begin{array}{c}\text { Non-OECD } \\
(4)\end{array}$ & $\begin{array}{c}\text { Science } \\
\text { (5) }\end{array}$ & $\begin{array}{l}\text { Reading } \\
\text { (6) }\end{array}$ & (7) & (8) \\
\hline Patience & $\begin{array}{l}1.296^{* * *} \\
(0.133)\end{array}$ & $\begin{array}{c}0.698^{* * *} \\
(0.169)\end{array}$ & $\begin{array}{c}0.963^{* * *} \\
(0.180)\end{array}$ & $\begin{array}{l}1.165^{* *} \\
(0.516)\end{array}$ & $\begin{array}{c}1.121^{* * *} \\
(0.121)\end{array}$ & $\begin{array}{c}1.108^{* * *} \\
(0.113)\end{array}$ & $\begin{array}{c}1.181^{* * *} \\
(0.121)\end{array}$ & $\begin{array}{c}1.119^{* * *} \\
(0.120)\end{array}$ \\
\hline Risk-taking & $\begin{array}{c}-1.320^{* * *} \\
(0.189)\end{array}$ & $\begin{array}{l}-0.371^{*} \\
(0.221)\end{array}$ & $\begin{array}{c}-0.996^{* * *} \\
(0.271)\end{array}$ & $\begin{array}{c}-1.141^{* * *} \\
(0.333)\end{array}$ & $\begin{array}{c}-1.169^{* * *} \\
(0.180)\end{array}$ & $\begin{array}{c}-1.134^{* * *} \\
(0.198)\end{array}$ & $\begin{array}{c}-1.213^{* * *} \\
(0.180)\end{array}$ & $\begin{array}{c}-1.143^{* * *} \\
(0.173)\end{array}$ \\
\hline Item nonresponse & & & & & & & $\begin{array}{c}-3.161^{* * *} \\
(0.163)\end{array}$ & $\begin{array}{c}-2.875^{* * *} \\
(0.152)\end{array}$ \\
\hline Item nonresponse (country mean) & & & & & & & & $\begin{array}{c}-4.052^{* * *} \\
(1.030)\end{array}$ \\
\hline Baseline controls & Yes & Yes & Yes & Yes & Yes & Yes & Yes & Yes \\
\hline Observations & $1,751,822$ & 192,736 & $1,416,506$ & 575,770 & $1,992,276$ & $1,950,722$ & $1,992,276$ & $1,992,276$ \\
\hline Countries & 49 & 49 & 27 & 22 & 49 & 49 & 49 & 49 \\
\hline$R^{2}$ & 0.214 & 0.083 & 0.112 & 0.085 & 0.179 & 0.189 & 0.244 & 0.250 \\
\hline
\end{tabular}

Notes: Dependent variable: PISA test score in math (col. 1-4 and 7-8), science (col. 5), and reading (col. 6), respectively, in all PISA waves 2000-2018. Least squares regression weighted by students' sampling probability. Item nonresponse refers to the share of questions not answered in the student background questionnaire following the achievement test. Baseline control variables: student gender, age, and migration status; imputation dummies; and wave fixed effects. Robust standard errors adjusted for clustering at the country level in parentheses. Significance level: ${ }^{* * *} 1$ percent, ${ }^{* *} 5$ percent, ${ }^{*} 10$ percent. Data sources: PISA international student achievement test, 2000-2018; Falk et al. (2018). 
Table 3: Culture and student achievement: Migrant analysis

\begin{tabular}{|c|c|c|c|c|c|c|c|c|}
\hline & \multicolumn{3}{|c|}{$\begin{array}{l}\text { Residence-country } \\
\text { and wave fixed effects }\end{array}$} & \multicolumn{5}{|c|}{ Residence-country by wave fixed effects } \\
\hline & \multicolumn{7}{|c|}{ Baseline controls } & \multirow{2}{*}{$\begin{array}{c}\text { Extended } \\
\text { controls } \\
(8)\end{array}$} \\
\hline & (1) & (2) & (3) & $(4)$ & (5) & (6) & (7) & \\
\hline Patience (country-of-origin) & $\begin{array}{c}0.776^{* * *} \\
(0.114)\end{array}$ & & $\begin{array}{l}0.929^{* * *} \\
(0.117)\end{array}$ & $\begin{array}{l}0.779^{* * *} \\
(0.115)\end{array}$ & & $\begin{array}{l}0.931^{* * *} \\
(0.116)\end{array}$ & $\begin{array}{l}1.032^{* * *} \\
(0.133)\end{array}$ & $\begin{array}{l}0.667^{* * *} \\
(0.100)\end{array}$ \\
\hline Risk-taking (country-of-origin) & & $\begin{array}{c}0.188 \\
(0.202)\end{array}$ & $\begin{array}{c}-0.291^{* *} \\
(0.125)\end{array}$ & & $\begin{array}{c}0.183 \\
(0.210)\end{array}$ & $\begin{array}{c}-0.294^{* *} \\
(0.122)\end{array}$ & $\begin{array}{c}-0.449^{* * *} \\
(0.140)\end{array}$ & $\begin{array}{c}-0.352^{* * *} \\
(0.092)\end{array}$ \\
\hline Positive reciprocity (country-of-origin) & & & & & & & $\begin{array}{l}-0.141 \\
(0.157)\end{array}$ & \\
\hline Negative reciprocity (country-of-origin) & & & & & & & $\begin{array}{c}0.082 \\
(0.087)\end{array}$ & \\
\hline Altruism (country-of-origin) & & & & & & & $\begin{array}{c}0.042 \\
(0.144)\end{array}$ & \\
\hline Trust (country-of-origin) & & & & & & & $\begin{array}{l}-0.173 \\
(0.138)\end{array}$ & \\
\hline Residence-country fixed effects & Yes & Yes & Yes & Yes & Yes & Yes & Yes & Yes \\
\hline Wave fixed effects & Yes & Yes & Yes & Yes & Yes & Yes & Yes & Yes \\
\hline Residence-country by wave fixed effects & No & No & No & Yes & Yes & Yes & Yes & Yes \\
\hline Baseline controls & Yes & Yes & Yes & Yes & Yes & Yes & Yes & Yes \\
\hline Extended controls & No & No & No & No & No & No & No & Yes \\
\hline Observations & 80,398 & 80,398 & 80,398 & 80,398 & 80,398 & 80,398 & 80,398 & 80,398 \\
\hline Countries of origin & 58 & 58 & 58 & 58 & 58 & 58 & 58 & 58 \\
\hline Residence countries & 48 & 48 & 48 & 48 & 48 & 48 & 48 & 48 \\
\hline$R^{2}$ & 0.265 & 0.247 & 0.267 & 0.273 & 0.256 & 0.275 & 0.277 & 0.364 \\
\hline
\end{tabular}

Notes: Dependent variable: PISA math test score, waves 2003-2018. Least squares regressions. Col. 1-3 include 48 fixed effects for residence countries and six fixed effects for waves; col. 4-8 include 180 fixed effects for each residence-country by wave cell. Sample: students with both parents not born in the country where the student attends school. Baseline control variables: student gender, age, dummy for OECD country of origin, imputation dummies. Extended control variables: baseline controls plus parental education, parental occupation, books at home, computer at home, language spoken at home; school location, school size, share of fully certified teachers at school, shortage of educational material; country-of-origin GDP per capita. Robust standard errors adjusted for clustering at the country level in parentheses. Significance level: ${ }^{* * *} 1$ percent, ${ }^{* *} 5$ percent, ${ }^{*} 10$ percent. Data sources: PISA international student achievement test, $2000-$ 2018; Falk et al. (2018). 
Table 4: Migrant analysis: Subsamples, additional subjects, and test-taking effort

\begin{tabular}{|c|c|c|c|c|c|c|c|}
\hline & \multicolumn{2}{|c|}{ Country subsamples } & \multicolumn{2}{|c|}{ Additional subjects } & \multicolumn{3}{|c|}{ Test-taking effort } \\
\hline & $\begin{array}{l}\text { OECD } \\
(1)\end{array}$ & $\begin{array}{c}\text { Non-OECD } \\
\text { (2) }\end{array}$ & $\begin{array}{c}\text { Science } \\
\text { (3) }\end{array}$ & $\begin{array}{c}\text { Reading } \\
\text { (4) }\end{array}$ & (5) & (6) & (7) \\
\hline Patience (country-of-origin) & $\begin{array}{c}1.028^{* * *} \\
(0.105)\end{array}$ & $\begin{array}{c}0.812^{* * *} \\
(0.185)\end{array}$ & $\begin{array}{c}0.995^{* * *} \\
(0.143)\end{array}$ & $\begin{array}{c}0.844^{* * *} \\
(0.144)\end{array}$ & $\begin{array}{c}0.890^{* * *} \\
(0.114)\end{array}$ & $\begin{array}{l}1.021^{* * *} \\
(0.100)\end{array}$ & $\begin{array}{c}0.977^{* * *} \\
(0.105)\end{array}$ \\
\hline Risk-taking (country-of-origin) & $\begin{array}{c}-0.289^{* *} \\
(0.132)\end{array}$ & $\begin{array}{c}-0.454^{* *} \\
(0.177)\end{array}$ & $\begin{array}{l}-0.192 \\
(0.124)\end{array}$ & $\begin{array}{l}-0.106 \\
(0.133)\end{array}$ & $\begin{array}{c}-0.286^{* *} \\
(0.119)\end{array}$ & $\begin{array}{c}-0.307^{* *} \\
(0.120)\end{array}$ & $\begin{array}{c}-0.303^{* *} \\
(0.114)\end{array}$ \\
\hline Item nonresponse & & & & & $\begin{array}{c}-2.993^{* * *} \\
(0.233)\end{array}$ & & $\begin{array}{c}-3.218^{* * *} \\
(0.171)\end{array}$ \\
\hline Item nonresponse (country-of-origin mean) & & & & & & & $\begin{array}{l}-3.319^{*} \\
(1.691)\end{array}$ \\
\hline Residence-country by wave fixed effects & Yes & Yes & Yes & Yes & Yes & Yes & Yes \\
\hline Baseline controls & Yes & Yes & Yes & Yes & Yes & Yes & Yes \\
\hline Observations & 28,519 & 51,879 & 80,398 & 80,398 & 80,398 & 36,668 & 36,668 \\
\hline Countries of origin & 24 & 34 & 58 & 58 & 58 & 41 & 41 \\
\hline Residence countries & 31 & 38 & 48 & 48 & 48 & 45 & 45 \\
\hline$R^{2}$ & 0.176 & 0.309 & 0.253 & 0.239 & 0.310 & 0.178 & 0.234 \\
\hline
\end{tabular}

Notes: Dependent variable: PISA test score in math (col. 1-2 and 5-7), science (col. 3), and reading (col. 4), respectively, waves 2003-2018. Least squares regressions. Sample: students with both parents not born in the country where the student attends school. Item nonresponse refers to the share of questions not answered in the student background questionnaire following the achievement test. Baseline control variables: student gender, age, dummy for OECD country of origin, imputation dummies. Robust standard errors adjusted for clustering at the country level in parentheses. Significance level: ${ }^{* * *} 1$ percent, ${ }^{* *} 5$ percent, ${ }^{*} 10$ percent. Data sources: PISA international student achievement test, 2000-2018; Falk et al. (2018). 
Table 5: Migrant analysis: Subgroups by age of migration and language spoken at home

\begin{tabular}{|c|c|c|c|c|c|c|}
\hline & \multirow{3}{*}{$\begin{array}{c}\begin{array}{c}\text { Second } \\
\text { generation }\end{array} \\
(1)\end{array}$} & \multicolumn{3}{|c|}{ First generation } & \multicolumn{2}{|c|}{ Language spoken at home } \\
\hline & & \multirow{2}{*}{$\begin{array}{l}\text { All } \\
(2)\end{array}$} & \multirow{2}{*}{$\begin{array}{c}\text { Before age } 6 \\
\text { (3) }\end{array}$} & \multirow{2}{*}{$\begin{array}{c}\text { After age } 6 \\
\text { (4) }\end{array}$} & \multirow{2}{*}{$\begin{array}{c}\text { Residence } \\
\text { (5) }\end{array}$} & \multirow{2}{*}{$\begin{array}{l}\text { Other } \\
(6)\end{array}$} \\
\hline & & & & & & \\
\hline Patience (country-of-origin) & $\begin{array}{c}1.023^{* * *} \\
(0.143)\end{array}$ & $\begin{array}{c}0.955^{* * *} \\
(0.120)\end{array}$ & $\begin{array}{l}1.010^{* * *} \\
(0.156)\end{array}$ & $\begin{array}{c}0.981^{* * *} \\
(0.103)\end{array}$ & $\begin{array}{c}0.718^{* * *} \\
(0.117)\end{array}$ & $\begin{array}{c}0.883^{* * *} \\
(0.151)\end{array}$ \\
\hline Risk-taking (country-of-origin) & $\begin{array}{c}-0.458^{* * *} \\
(0.127)\end{array}$ & $\begin{array}{c}-0.185 \\
(0.145)\end{array}$ & $\begin{array}{l}-0.228 \\
(0.145)\end{array}$ & $\begin{array}{l}-0.153 \\
(0.146)\end{array}$ & $\begin{array}{c}-0.305^{* *} \\
(0.115)\end{array}$ & $\begin{array}{c}-0.508^{* * *} \\
(0.165)\end{array}$ \\
\hline Residence-country by wave fixed effects & Yes & Yes & Yes & Yes & Yes & Yes \\
\hline Baseline controls & Yes & Yes & Yes & Yes & Yes & Yes \\
\hline Observations & 47,369 & 33,029 & 14,459 & 16,835 & 48,556 & 24,520 \\
\hline Countries of origin & 56 & 57 & 51 & 55 & 56 & 57 \\
\hline Residence countries & 48 & 48 & 47 & 48 & 48 & 48 \\
\hline 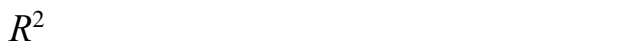 & 0.297 & 0.263 & 0.298 & 0.258 & 0.298 & 0.238 \\
\hline
\end{tabular}

Notes: Dependent variable: PISA math test score, waves 2003-2018. Least squares regressions. Sample: students with both parents not born in the country where the student attends school. Second generation: migrant students born in the country of residence. First generation: migrant students born in the country of origin; split between whether they migrated to the country of residence before or after age 6 in col. 3 and 4. Baseline control variables: student gender, age, dummy for OECD country of origin, imputation dummies. Robust standard errors adjusted for clustering at the country level in parentheses. Significance level: ${ }^{* * *} 1$ percent, ** 5 percent, * 10 percent. Data sources: PISA international student achievement test, 2000-2018; Falk et al. (2018). 
Table 6: Migrant analysis: Different definitions of migrants

\begin{tabular}{|c|c|c|c|c|c|c|c|c|}
\hline & \multicolumn{3}{|c|}{ Narrow definition } & \multicolumn{4}{|c|}{ Wide definition } & \multirow{2}{*}{$\begin{array}{l}\text { Dropping countries } \\
\text { of origin with } \\
<50 \text { observations } \\
\text { (8) }\end{array}$} \\
\hline & $\begin{array}{c}\text { Mother's } \\
\text { origin } \\
\text { (1) }\end{array}$ & $\begin{array}{c}\text { Parental } \\
\text { average } \\
\text { (2) }\end{array}$ & $\begin{array}{c}\text { Separate } \\
\text { (3) }\end{array}$ & $\begin{array}{c}\text { Mother's } \\
\text { origin } \\
(4)\end{array}$ & $\begin{array}{c}\text { Father's } \\
\text { origin } \\
\text { (5) }\end{array}$ & $\begin{array}{c}\text { Parental } \\
\text { average } \\
\text { (6) }\end{array}$ & $\begin{array}{c}\text { Separate } \\
\text { (7) }\end{array}$ & \\
\hline Patience (mother's country-of-origin) & $\begin{array}{c}0.931^{* * *} \\
(0.109)\end{array}$ & & $\begin{array}{c}0.343^{* * *} \\
(0.069)\end{array}$ & $\begin{array}{c}0.861^{* * *} \\
(0.109)\end{array}$ & & & $\begin{array}{c}0.349^{* * *} \\
(0.070)\end{array}$ & \\
\hline Risk-taking (mother's country-of-origin) & $\begin{array}{c}-0.292^{* *} \\
(0.126)\end{array}$ & & $\begin{array}{c}0.032 \\
(0.086)\end{array}$ & $\begin{array}{c}-0.228^{*} \\
(0.121)\end{array}$ & & & $\begin{array}{c}0.038 \\
(0.087)\end{array}$ & \\
\hline Patience (father's country-of-origin) & & & $\begin{array}{c}0.629^{* * *} \\
(0.090)\end{array}$ & & $\begin{array}{c}0.858^{* * *} \\
(0.112)\end{array}$ & & $\begin{array}{c}0.627^{* * *} \\
(0.093)\end{array}$ & $\begin{array}{c}0.939^{* * *} \\
(0.116)\end{array}$ \\
\hline Risk-taking (father's country-of-origin) & & & $\begin{array}{c}-0.339^{* * *} \\
(0.090)\end{array}$ & & $\begin{array}{l}-0.233^{*} \\
(0.119)\end{array}$ & & $\begin{array}{c}-0.336^{* * *} \\
(0.093)\end{array}$ & $\begin{array}{c}-0.299^{* *} \\
(0.122)\end{array}$ \\
\hline Patience (average parents' country-of-origin) & & $\begin{array}{c}0.941^{* * *} \\
(0.115)\end{array}$ & & & & $\begin{array}{c}0.858^{* * *} \\
(0.111)\end{array}$ & & \\
\hline Risk-taking (average parents’ country-of-origin) & & $\begin{array}{c}-0.273^{* *} \\
(0.124)\end{array}$ & & & & $\begin{array}{c}-0.217^{*} \\
(0.120)\end{array}$ & & \\
\hline Residence-country by wave fixed effects & Yes & Yes & Yes & Yes & Yes & Yes & Yes & Yes \\
\hline Baseline controls & Yes & Yes & Yes & Yes & Yes & Yes & Yes & Yes \\
\hline Observations & 80,194 & 83,798 & 76,796 & 140,951 & 141,155 & 145,506 & 85,167 & 80,221 \\
\hline Countries of origin & 57 & 58 & 58 & 60 & 60 & 60 & 59 & 46 \\
\hline Residence countries & 48 & 48 & 48 & 48 & 48 & 48 & 48 & 48 \\
\hline$R^{2}$ & 0.278 & 0.274 & 0.280 & 0.255 & 0.254 & 0.254 & 0.279 & 0.275 \\
\hline
\end{tabular}

Notes: Dependent variable: PISA math test score, waves 2003-2018. Least squares regressions. Sample: migrant students; see text for narrow and wide definition of migrant status. Baseline control variables: student gender, age, dummy for OECD country of origin, imputation dummies. Robust standard errors adjusted for clustering at the country level in parentheses. Significance level: ${ }^{* * *} 1$ percent, ${ }^{* *} 5$ percent, ${ }^{*} 10$ percent. Data sources: PISA international student achievement test, 2000-2018; Falk et al. (2018). 
Table 7: Migrant analysis: Addressing selectivity of migrants

\begin{tabular}{|c|c|c|c|c|c|c|c|}
\hline & \multirow{3}{*}{$\begin{array}{l}\text { Continent-of-origin } \\
\text { fixed effects } \\
\text { (1) }\end{array}$} & \multirow{3}{*}{$\begin{array}{c}\text { Cultural } \\
\text { variance } \\
(2)\end{array}$} & \multicolumn{3}{|c|}{ Migration distance } & \multirow{2}{*}{\multicolumn{2}{|c|}{$\begin{array}{l}\text { Selectivity of migrant } \\
\text { schooling }\end{array}$}} \\
\hline & & & \multirow{2}{*}{$\begin{array}{c}\text { Geographical } \\
\text { (3) }\end{array}$} & \multicolumn{2}{|c|}{ Cultural } & & \\
\hline & & & & (4) & (5) & (6) & (7) \\
\hline Patience (country-of-origin) & $\begin{array}{l}0.976^{* * *} \\
(0.125)\end{array}$ & $\begin{array}{c}0.818^{* * *} \\
(0.191)\end{array}$ & $\begin{array}{l}0.925^{* * *} \\
(0.117)\end{array}$ & $\begin{array}{c}0.933^{* * *} \\
(0.149)\end{array}$ & $\begin{array}{l}0.743^{* * *} \\
(0.160)\end{array}$ & $\begin{array}{l}0.987^{* * *} \\
(0.105)\end{array}$ & $\begin{array}{l}1.048^{* * *} \\
(0.106)\end{array}$ \\
\hline Risk-taking (country-of-origin) & $\begin{array}{l}-0.331^{* *} \\
(0.127)\end{array}$ & $\begin{array}{l}-0.284^{* *} \\
(0.141)\end{array}$ & $\begin{array}{l}-0.302^{* *} \\
(0.121)\end{array}$ & $\begin{array}{l}-0.539^{* * *} \\
(0.143)\end{array}$ & $\begin{array}{l}-0.855^{* * *} \\
(0.161)\end{array}$ & $\begin{array}{c}-0.300^{* * *} \\
(0.109)\end{array}$ & $\begin{array}{c}-0.411^{* * *} \\
(0.093)\end{array}$ \\
\hline Std. dev. of patience (country-of-origin) & & $\begin{array}{c}0.285 \\
(0.307)\end{array}$ & & & & & \\
\hline Std. dev. of risk-taking (country-of-origin) & & $\begin{array}{l}-0.241 \\
(0.372)\end{array}$ & & & & & \\
\hline Geographical distance (in 1000 km) & & & $\begin{array}{l}-0.010 \\
(0.007)\end{array}$ & & & & \\
\hline Patience distance & & & & & $\begin{array}{l}-0.198 \\
(0.133)\end{array}$ & & \\
\hline $\begin{array}{l}\text { Patience distance } \\
\quad \times \text { Patience (country-of-origin) }\end{array}$ & & & & & $\begin{array}{l}-0.232 \\
(0.374)\end{array}$ & & \\
\hline Risk-taking distance & & & & & $\begin{array}{c}0.093 \\
(0.097)\end{array}$ & & \\
\hline $\begin{array}{l}\text { Risk-taking distance } \\
\quad \times \text { Risk-taking (country-of-origin) }\end{array}$ & & & & & $\begin{array}{l}0.980^{* * *} \\
(0.209)\end{array}$ & & \\
\hline Selectivity of migrant schooling & & & & & & & $\begin{array}{c}1.269^{* * *} \\
(0.379)\end{array}$ \\
\hline Observations & 80,398 & 80,398 & 80,398 & 29,019 & 29,019 & 39,725 & 39,725 \\
\hline Countries of origin & 58 & 58 & 58 & 49 & 49 & 44 & 44 \\
\hline Residence countries & 48 & 48 & 48 & 26 & 26 & 20 & 20 \\
\hline$R^{2}$ & 0.276 & 0.275 & 0.276 & 0.236 & 0.240 & 0.192 & 0.196 \\
\hline
\end{tabular}

Notes: Dependent variable: PISA math test score, waves 2003-2018. Least squares regressions. Sample: students with both parents not born in the country where the student attends school. All specifications include residence-country by wave fixed effects and baseline controls (student gender, age, dummy for OECD country of origin, imputation dummies). Column-specific additional control variables: Col. 1: fixed effects for continent of origin. Col. 2: standard deviation of patience and risk-taking, respectively, in country of origin obtained from individual-level GPS data using individuals’ sampling probability. Col. 3: geographical distance between respective residence and origin country according to most populous cities. Col. 5: difference in patience and risk-taking between respective residence and origin country (all variables demeaned). Col. 7: percentile of migrants' educational attainment on respective country-of-origin schooling distribution for each residence country. Robust standard errors adjusted for clustering at the country level in parentheses. Significance level: ${ }^{* * *} 1$ percent, ${ }^{* *} 5$ percent, ${ }^{*} 10$ percent. Data sources: PISA international student achievement test, 2003-2018; Falk et al. (2018). 
Table 8: The association of culture with proximate inputs in the education production function

\begin{tabular}{|c|c|c|c|c|}
\hline & $\begin{array}{c}\text { Family inputs } \\
\text { (1) }\end{array}$ & $\begin{array}{c}\text { School inputs } \\
\text { (2) }\end{array}$ & $\begin{array}{l}\text { Institutional inputs } \\
\text { (3) }\end{array}$ & $\begin{array}{c}\text { Residual } \\
\text { (4) }\end{array}$ \\
\hline \multicolumn{5}{|l|}{ Upper bound } \\
\hline Patience & $\begin{array}{c}0.800^{* * *} \\
(0.087)\end{array}$ & $\begin{array}{c}0.069^{* * *} \\
(0.021)\end{array}$ & $\begin{array}{l}0.060 \\
(0.037)\end{array}$ & $\begin{array}{l}0.289^{* * *} \\
(0.095)\end{array}$ \\
\hline Risk-taking & $\begin{array}{c}-0.500^{* * *} \\
(0.139)\end{array}$ & $\begin{array}{l}-0.017 \\
(0.033)\end{array}$ & $\begin{array}{l}-0.066 \\
(0.059)\end{array}$ & $\begin{array}{r}-0.690^{* * *} \\
(0.151)\end{array}$ \\
\hline $\begin{array}{l}\text { Observations } \\
R^{2}\end{array}$ & $\begin{array}{c}49 \\
0.646\end{array}$ & $\begin{array}{c}49 \\
0.200\end{array}$ & $\begin{array}{c}49 \\
0.061\end{array}$ & $\begin{array}{c}49 \\
0.335\end{array}$ \\
\hline \multicolumn{5}{|l|}{ Lower bound } \\
\hline Patience & $\begin{array}{c}0.382^{* * *} \\
(0.062)\end{array}$ & $\begin{array}{l}0.044^{* *} \\
(0.019)\end{array}$ & $\begin{array}{l}-0.012 \\
(0.027)\end{array}$ & \\
\hline Risk-taking & $\begin{array}{c}-0.325^{* * *} \\
(0.099)\end{array}$ & $\begin{array}{c}0.003 \\
(0.031)\end{array}$ & $\begin{array}{l}-0.009 \\
(0.043)\end{array}$ & \\
\hline $\begin{array}{l}\text { Observations } \\
R^{2}\end{array}$ & $\begin{array}{c}49 \\
0.461\end{array}$ & $\begin{array}{c}49 \\
0.120\end{array}$ & $\begin{array}{c}49 \\
0.008\end{array}$ & \\
\hline
\end{tabular}

Notes: Country-level least squares regressions. Dependent variables indicated in column headers. Upper/lower bound refers to whether the cultural variables are included in the underlying estimation of coefficients for the combination of the three input vectors. See text for details. Robust standard errors in parentheses.

Significance level: ${ }^{* * *} 1$ percent, ${ }^{* *} 5$ percent, ${ }^{*} 10$ percent. Data sources: PISA international student achievement test, 2000-2018; Falk et al. (2018). 
Figure 1: Patience and risk-taking across countries

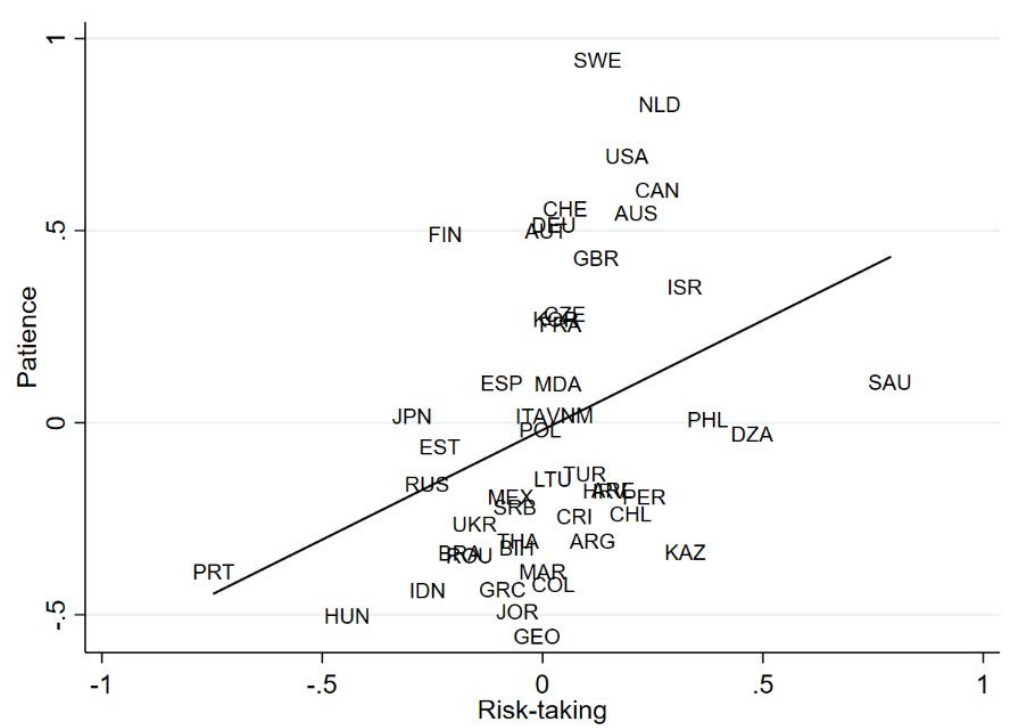

Notes: Country averages. Data source: Folk et al. (2018). 
Figure 2: Intertemporal cultural traits and student achievement across countries
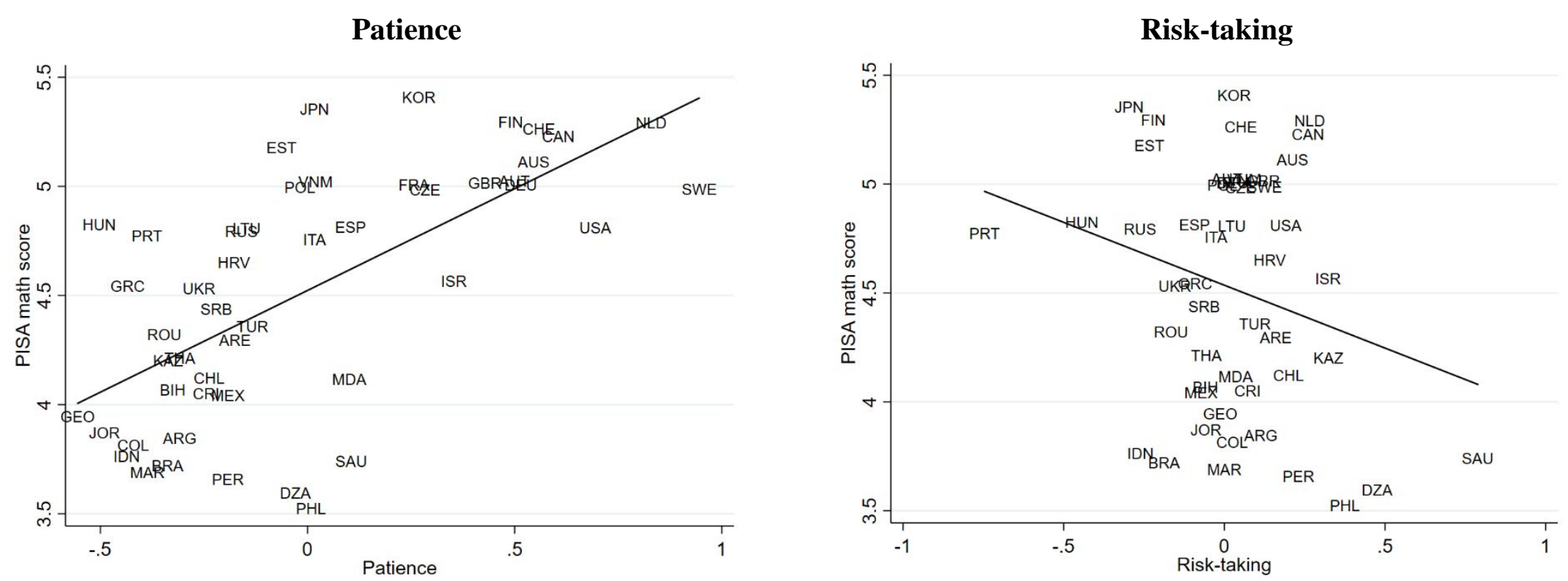

Patience (conditional on risk-taking)

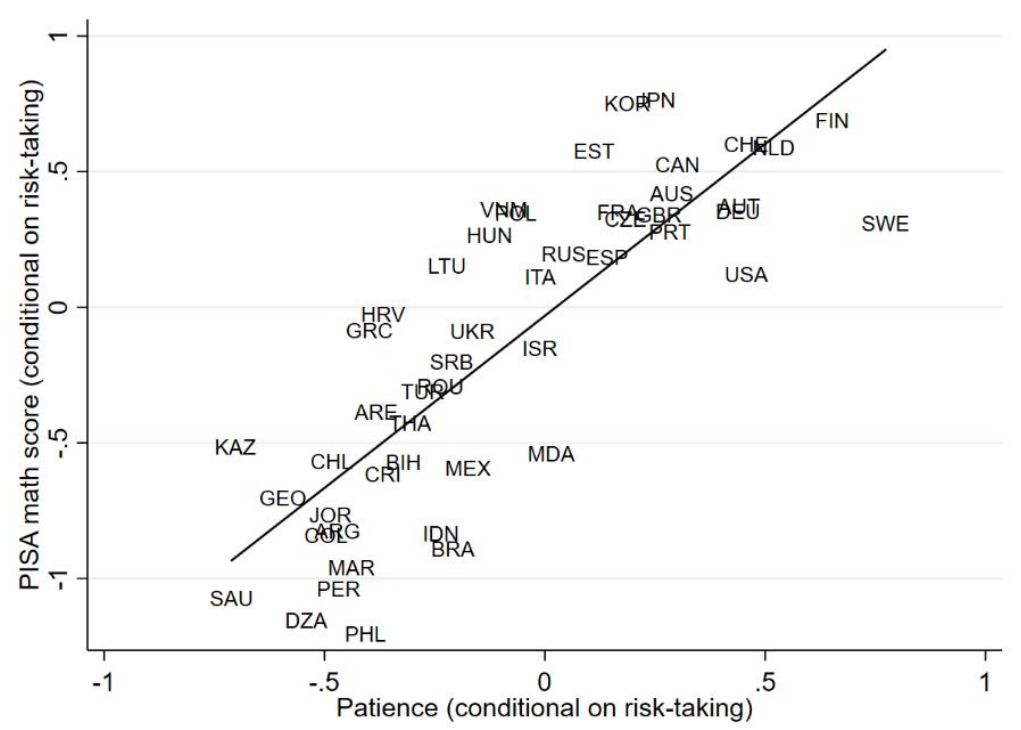

Risk-taking (conditional on patience)

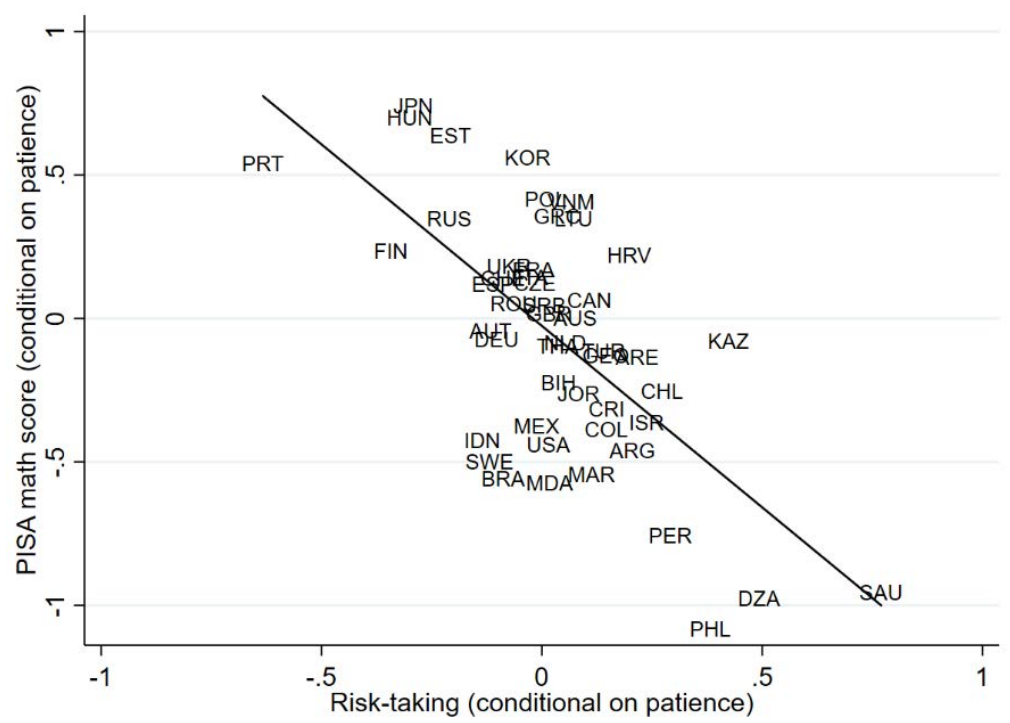

Notes: PISA math score: average student achievement, 2000-2018. Data sources: PISA international student achievement test, 2000-2018; Falk et al. (2018). 